\title{
Verb movement and the lack of verb-doubling VP-topicalization in Germanic
}

\author{
Johannes Hein ${ }^{1}$
}

Received: 22 August 2018 / Accepted: 26 November 2019 / Published online: 3 April 2021

(c) The Author(s) 2021

\begin{abstract}
In the absence of a stranded auxiliary or modal, VP-topicalization in most Germanic languages gives rise to the presence of a dummy verb meaning 'do'. Cross-linguistically, this is a rather uncommon strategy as comparable VP-fronting constructions in other languages, e.g. Hebrew, Polish, and Portuguese, among many others, exhibit verb doubling. A comparison of several recent approaches to verb doubling in VP-fronting reveals that it is the consequence of VP-evacuating head movement of the verb to some higher functional head, which saves the (low copy of the) verb from undergoing copy deletion as part of the low VP copy in the VP-topicalization dependency. Given that almost all Germanic languages have such V-salvaging head movement, namely V-to-C movement, but do not show verb doubling, this paper suggests that V-raising is exceptionally impossible in VP-topicalization clauses and addresses the question of why it is blocked. After discussing and rejecting some conceivable explanations for the lack of verb doubling, I propose that the blocking effect arises from a bleeding interaction between $\mathrm{V}$-to-C movement and VP-to-SpecCP movement. As both operations are triggered by the same head, i.e. C, the VP is always encountered first by a downward search algorithm. Movement of VP then freezes it and its lower copies for subextraction precluding subsequent V-raising. Crucially, this implies that there is no V-to-T raising in most Germanic languages. V2 languages with V-to-T raising, e.g. Yiddish, are correctly predicted to not exhibit the blocking effect.
\end{abstract}

Keywords Verb doubling $\cdot$ Head movement $\cdot$ VP-topicalization $\cdot$ Copy deletion · V-to-T movement $\cdot$ V-to-C movement $\cdot$ Verb second $\cdot$ Freezing

This research was funded by the Deutsche Forschungsgemeinschaft (DFG, German Research Foundation)—Project Number 317633480—SFB 1287, project C05.

\footnotetext{
$凶$ Johannes Hein

johannes.hein@uni-potsdam.de

1 Department Linguistik, Universität Potsdam, Karl-Liebknecht-Straße 24-25, 14476 Potsdam, Germany
} 


\section{Introduction}

In a number of languages it is possible to displace the verb phrase, understood to be the verb and any associated direct or indirect objects, into the left periphery of the clause. Commonly, this displacement is associated with a topic or focus interpretation on the displaced constituent and some kind of contrast. In the absence of an inflectable auxiliary or modal verb, one often finds that a finite copy of the displaced lexical verb appears. This is the case in Polish (1a) and Hebrew (1b) as well as in a vast number of other languages including Brazilian Portuguese (Bastos-Gee 2009), Buli (Hiraiwa 2005a, b), Dagaare (Hiraiwa and Bodomo 2008), Krachi (Kandybowicz and Torrence 2016), Mani (Childs 2011), Russian (Abels 2001; Aboh and Dyakonova 2009), Spanish (Vicente 2007, 2009), Vietnamese (Tran 2011; Trinh 2011), Yiddish (Cable 2004), and Yoruba (Manfredi 1993).

(1) a. [vp Wypić herbatę ] (to) Marek wypije, ale nie wypije kawy. drink.INF tea TO Marek will.drink but not will.drink coffee

'As for drinking tea, Marek will drink it, but he will not drink coffee.'

(Polish, Bondaruk 2012, 55)

b. [vp Liknot et ha-praxim ], hi kanta.

buy.INF ACC the-flowers she bought

'As for buying the flowers, she bought (them).'

(Hebrew, Landau 2006, 37)

As will be shown in Sect. 2, the most prominent recent analyses of this type of verb doubling link the overt pronunciation of the lower (finite) verb copy to the fact that the V-head has to undergo head-movement to some higher functional head like Asp or T independently (see, e.g., Nunes 2004; Landau 2006; Aboh and Dyakonova 2009; Trinh 2011; LaCara 2016a).

Most Germanic languages, ${ }^{1}$ however, exhibit a different pattern. When VPtopicalization occurs in the absence of an auxiliary or modal, instead of a gap or a verb copy there is a dummy verb usually translatable as $d o$. This is shown for German, Dutch, Norwegian, ${ }^{2}$ Danish, Swedish, and English VP-topicalization in (2a-f).

a. [vp Lange Dissertationen lesen ] tut doch heute niemand mehr. long dissertations read.INF does $\mathrm{PRT}$ todayno.one more 'As for reading long dissertations, no-one does it anymore.'

(German)

b. [vp Haar verraden ] doet hij niet. her betray does he not 'He doesn't betray her.'

(Dutch, Broekhuis and Corver 2015, 1043)

c. [vP $(\AA)$ lese bok-en ] gjør hun i dag.

to read.INF book-DEF does she in day

'As for reading the book, she does it today.'

(Norwegian)

\footnotetext{
1 Hereafter, the term 'Germanic' will be used mainly to refer to the five languages Danish, Dutch, German, Norwegian, and Swedish (sometimes including English, Afrikaans, and Yiddish, as well).

2 If not indicated otherwise, all Norwegian judgements are due to Siri M. Gjersøe, and all German judgements are mine.
} 
d. ...og [vp kørde/køre bilen ] gjorde han. and droveldrive car.DEF did he '....and drive the car, he did.'

(Danish, Platzack 2008, 280)

e. [vp Läser boken ] gör han nu. reads book.DEF does he now

'Reading the book he is now.' (Swedish, Källgren and Prince 1989, 47)

f. John wanted to read the article and [vp read the article ] he did.

Outside of the Germanic language family, only a handful of languages have been reported to exhibit this pattern, namely Hausa, Skou, Wolof, and possibly also Welsh, Basque, and Breton (for details, see Hein 2018). The behaviour of the Germanic languages with regard to gap avoidance in VP-topicalization seems particularly unexpected in light of the fact that, with the exception of English, they all show at least some degree of V-to-higher-functional-head movement, i.e. V-to-C movement. Given that head movement is syntactic, it should always precede post-syntactic copy deletion (CD) of the low VP copy, giving rise to verb doubling. Instead, it seems that head movement in Germanic is bled by deletion of the low VP copy in the post-syntactic component and must therefore also be a post-syntactic operation (see among others Chomsky 2001; Boeckx and Stjepanović 2001; Merchant 2002; Schoorlemmer and Temmerman 2012; Platzack 2013; Zwart 2017). It is further noteworthy that English behaves like the other Germanic languages, despite lacking V2 and verb movement of any kind. As the nature and location of head movement has been debated again recently (Zwart 2017; Harizanov and Gribanova 2019; Arregi and Pietraszko 2020b) the phenomenon of verb doubling and its absence in VP-topicalization constructions might provide insights based on the underlying interaction of head movement and copy deletion.

In this paper, specifically, I argue that the Germanic peculiarity follows from the fact that verb movement targets $\mathrm{C}$ in most Germanic languages, while it targets a lower T/Asp head in most of the languages exhibiting verb doubling. Crucially, the triggers for both VP-movement and V-movement are therefore located on the same head. This peculiarity of Germanic languages coupled with some general properties of probing and movement, I argue, leads to VP-topicalization bleeding V-to-C movement and thus to a lack of verb doubling. A post-syntactic conception of head movement (Chomsky 2001; Boeckx and Stjepanović 2001; Hale and Keyser 2002; Merchant 2002; Schoorlemmer and Temmerman 2012; Platzack 2013; Zwart 2017; Korsah 2017) is therefore not necessary in order to account for the lack of verb doubling in Germanic. Rather, head movement can be treated as a true syntactic process (Lechner 2001, 2004, 2007; Baltin 2002; Iatridou and Zeijlstra 2010; Roberts 2010; Keine and Bhatt 2016; Gribanova 2017; Sailor 2018).

The paper is structured as follows. Sect. 2 provides some background on current analyses of verb doubling under $\mathrm{V}(\mathrm{P})$-fronting, detailing how they link the overt pronunciation of the low verb copy to head movement of V. I will discuss and reject some immediately conceivable explanations for the occurence of the dummy verb in Sect. 3 such as the independent presence of the dummy verb, the absence of head movement of $\mathrm{V}$, and base generation of the topicalized VP with the dummy verb as a VP-proform. In Sect. 4, I will develop an analysis in terms of bleeding and counter-bleeding between 
VP-movement and V-movement. Sect. 5 is concerned with a few ramifications of the present approach, in particular concerning the Germanic languages English, Yiddish, and Afrikaans, as well as some non-Germanic non-doubling languages. Further issues pertaining to embedded clauses are discussed in Sect. 6. Sect. 7 summarizes and concludes the paper.

\section{Background on verb doubling}

Since Koopman's (1984) widely received seminal work on verb-doubling verbfronting in Vata, a vast body of theoretical work on the topic has accumulated to date both on bare verb fronting (i.e., V-fronting) and VP-fronting (see, e.g., Piou 1982; Bernabé 1983; Lumsden and Lefebvre 1990; Larson and Lefebvre 1991; Dekydspotter 1992; Manfredi 1993; Stewart 1998; Aboh 1998, 2006; Koopman 2000; Abels 2001; Nunes 2004; Hiraiwa 2005b; Landau 2006; Vicente 2007, 2009; Harbour 2008; Kandybowicz 2008; Aboh and Dyakonova 2009; Bastos-Gee 2009; Trinh 2011; LaCara 2016a). However, most of them describe and analyse the phenomenon in one, sometimes a handful of languages. Nonetheless, all but one (LaCara 2016a) of the most recent approaches are embedded in the Copy Theory of Movement (Chomsky 1995; Nunes 1995) where instead of a trace or gap there is a copy of the movee left in the root of the dependency which is later deleted as part of a PF process of copy deletion. As Abels (2001) and Nunes (2004) point out, a straightforward way to conceive of the clause-internal verb copy in verb doubling constructions is as an exceptionally pronounced lower copy of a movement dependency as depicted in (3).

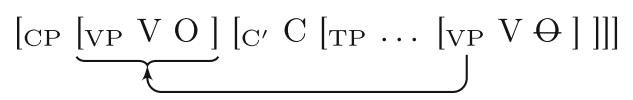

While the lower copy of the object in (3) undergoes deletion at PF (indicated by strikethrough) and will go unpronounced, the low $\mathrm{V}$ copy itself remains undeleted for some reason to be specified and will hence be pronounced. Thus, given that there are in fact arguments in favour of $\mathrm{V}(\mathrm{P})$-fronting involving movement, the only thing that is missing is an explanation for the exceptional non-deletion of the low verb copy at PF. Several such explanations have been put forward in the literature (e.g., Nunes 2004; Landau 2006; Kandybowicz 2008; Aboh and Dyakonova 2009; Trinh 2011; LaCara 2016a; Kandybowicz and Torrence 2016). As laid out in detail in what follows, even though they were each devised for only one/a few language(s), they uniformly derive verb doubling from the fact that the verb independently undergoes head movement (in whichever implementation) to a higher functional head, which causes it to be exempt from deletion.

\subsection{Linearization conflict (Nunes 2004)}

Revising and extending the ideas presented in his dissertation (Nunes 1995), Nunes (2004) proposes that the deletion of lower copies of a movement chain is the solution to contradicting linearization statements. His proposal rests on the assumption 
that linearization of a syntactic structure is derived from its hierarchical relations via the Linear Correspondence Axiom (LCA Kayne 1994) where c-command translates into linear precedence. The presence of two copies of an element $\mathrm{X}$ in two different positions, one being c-commanded by and the other c-commanding another element $\mathrm{Y}$, then gives rise to the following partial linearization statements:

- Y precedes X, because Y c-commands X.

- X precedes $\mathrm{Y}$, because $\mathrm{X}$ c-commands $\mathrm{Y}$.

This conflict is usually resolved by a process of Chain Reduction, which in the standard cases deletes all but the highest copy of a syntactic element.

Chain Reduction (Nunes 2004, 27)

Delete the minimal number of constituents of a nontrivial chain $\mathrm{CH}$ that suffices for $\mathrm{CH}$ to be mapped into a linear order in accordance with the LCA.

In cases of verb doubling in bare verb fronting, Nunes argues that the higher copy of the verb is morphologically reanalysed as forming a single terminal together with the attracting head to which it has (head-)moved (5). Appealing to a proposal by Chomsky (1995), Nunes assumes that the LCA does not apply word-internally and that the higher copy therefore becomes invisible for the LCA as soon as it is fused with the attracting head. Consequently, it will not trigger Chain Reduction because it no longer causes a linearization conflict.

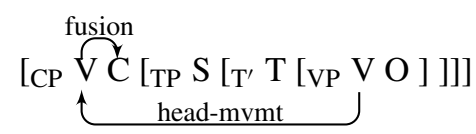

In summary, the pronunciation of two links of a verb movement chain is the result of one of these links being morphologically fused with another head thereby becoming invisible for the LCA and consequently for Chain Reduction.

Nunes (2004) does not discuss verb doubling in VP-fronting contexts in his book but one can in principle conceive of two different structures for verb phrase fronting: In the first structure, the VP moves as a whole phrase into the specifier of the attracting head ( $\mathrm{C}$ here, but Foc or Top are also candidates) (6a). In the alternative structure, first the $\mathrm{V}$ head adjoins to $\mathrm{C}$, then the object DP moves into the specifier of $\mathrm{CP}(6 \mathrm{~b})$.

$$
\begin{array}{ll}
\text { a. } & {\left[\mathrm{CP}[\mathrm{vP} \mathrm{V} \mathrm{O}]\left[\mathrm{C}^{\prime} \mathrm{C} \ldots[\mathrm{vp} \mathrm{V} \mathrm{O}]\right]\right]} \\
\mathrm{b} . & {\left[\mathrm{CP} \mathrm{O}\left[\mathrm{C}^{\prime}[\mathrm{C} \mathrm{V} \mathrm{C}] \ldots[\mathrm{vP} \mathrm{V} \mathrm{O}]\right]\right]}
\end{array}
$$

The second option can safely be discarded as it assigns the wrong constituency to the fronted verb phrase (though see Baltin 2006 on English VP-preposing) and, at least for most VO languages, also predicts the wrong linear order, namely OV, in the fronted verb phrase (see, e.g., the Hebrew and Polish examples in Sect. 1). The correct structure of VP-fronting must hence be (6a). However, here, the verbal head cannot morphologically fuse with the attracting head as they are not in a sisterhood relation. We would thus expect Chain Reduction to apply regularly, deleting the lower VP copy. This expectation is not borne out given the existence of a finite copy of the fronted verb in VP-fronting constructions in many languages, including Hebrew and Polish. 
This finite verb copy can only arise if the low $\mathrm{V}$ copy moves to $\mathrm{T}$ and fuses with it, rendering it invisible for the LCA. ${ }^{3}$

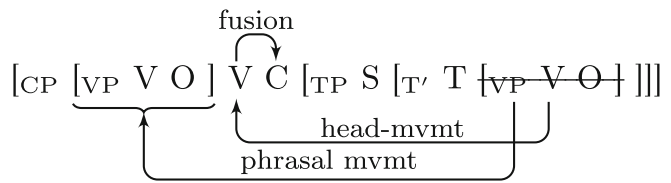

A fused head should only allow for insertion of a single vocabulary item. The fact that inflectional material (usually associated with the non-fused T head) occurs on the low $\mathrm{V}$ head, which is targeted for insertion of the verb, is accounted for if Fusion takes place after Vocabulary Insertion (as argued by Kandybowicz 2007).

Turning to Germanic VP-topicalization, we need an explanation for why V-to-C movement does not similarly lead to fusion of $\mathrm{V}$ and $\mathrm{C}$ (7), and eventually, to verb doubling, as expected under Nunes's (2004) approach. Simply stating that V does not fuse with $\mathrm{C}$ is an unsatisfactory solution.

\subsection{An edge constraint on copy deletion (Trinh 2011)}

Trinh $(2009,2011)$, in trying to account for verb doubling with bare verb fronting, proposes the following condition on the mechanism responsible for deletion of superfluous copies.

Edge Condition on Copy Deletion (ECCD, Trinh 2011, 31)

For any chain $(\alpha, \beta)$ where $\alpha$ is the higher and $\beta$ the lower copy of the moved constituent, deletion of $\beta$ requires that $\beta$ ends an XP.

In this formulation, $\beta$ ends an XP if and only if the last morpheme of $\beta$ coincides with the last morpheme of the XP. The underlying observation leading to (8) is that a majority of verb doubling languages are VO languages while multiple verb pronunciation is absent from OV languages despite them exhibiting verbal fronting. Under the assumption that verb fronting in addition to being remnant VP movement, can also be derived by $\bar{A}$-head movement of the verb into the left periphery, Trinh (2011) deduces three possible structure-types of verb fronting (9).

Possible underlying structures of verb fronting (Trinh 2011, 31)

a. [CP V ... [vp V O ] ]

b. $[\mathrm{CP} \mathrm{V} \ldots[\mathrm{VP} \mathrm{OV}]]$

c. $[\mathrm{CP}[\mathrm{VP} \ldots \mathrm{V} \ldots] \ldots[v \mathrm{P} v \mathrm{VP}]]$

In Type 1 (9a) V has undergone $\overline{\mathrm{A}}$-head movement. The lower V copy does not end an XP and therefore will not be deleted as it does not satisfy the ECCD. This type is supposedly instantiated by Hebrew and Vietnamese. In Type 2 (9b), V again has undergone $\overline{\mathrm{A}}$-head movement. Here however, the lower $\mathrm{V}$ copy is at the end of an XP, namely VP. The ECCD is thus fulfilled and the lower V copy is deleted. This structure

\footnotetext{
3 This general schema for the doubling of a head has also been argued to underly preposition doubling in Icelandic (see Jónsson 2008). 
is claimed to underly verb topicalization in German and Dutch. Finally, Type 3 (9c) has been generated by remnant VP movement, and the lower VP copy is deleted in accordance with the ECCD as it ends the $v \mathrm{P}$. This structure, Trinh argues, underlies verb topicalization in Swedish and Norwegian.

In summary, Trinh (2011) proposes that lower copies of a movement chain can only be deleted if they end a phrase. This Edge Condition on Copy Deletion predicts that SVO languages show verb doubling in verb fronting, whereas SOV languages exhibit a gap instead. Languages that are SVO but do not show verb doubling are argued to employ remnant verb phrase movement rather than $\overline{\mathrm{A}}$-head movement of $\mathrm{V}$ to SpecCP in verb fronting.

As is obvious from (9c), VP-fronting (be that a full or a remnant VP) in a head-initial language should never give rise to verb doubling, since the low VP copy always ends an XP, namely $v \mathrm{P}$ or TP, and should consequently undergo copy deletion. As Hebrew and Polish attest, this is quite the contrary of what is the case (also see data discussed in Manfredi 1993). However, if V-to-T movement is taken into consideration, the verb would be correctly expected to evade deletion. Although the lower copy of this head-movement chain does not end an XP, it is deleted as part of the low copy of the VP-chain, which does end an XP, leaving the higher copy to be pronounced. Ultimately, then, Trinh's (2011) approach can account for verb doubling under VP-fronting.

Concerning VP-topicalization in the Germanic languages, however, without further qualifications it leads us to expect V-to-C movement to have the same effect as V-to-T movement. It should evacuate the verb from the low VP copy prior to its deletion. Note further that this approach would possibly predict that head-final Germanic languages should not delete the low VP copy, as it does not end the $v \mathrm{P}$, given that some morpheme realizes the $v$ head.

\subsection{P-recoverability and Economy of Pronunciation (Landau 2006)}

For Landau (2006), the decision whether a copy is spelled out or deleted is based on its phonological/prosodic properties. Working in the Copy Theory of Movement, Landau's explanation for the fact that in most cases not all copies of a movement chain are pronounced is the economy constraint in (10), which triggers deletion at PF.

Economy of Pronunciation (Landau 2006, 57)

Delete all chain copies at PF up to P-recoverability.

The deletion operation thus applies freely in the PF component of grammar up to a certain boundary. This boundary is set by P-recoverability.

\section{$P$ (honological)-Recoverability (Landau 2006, 56)}

In a chain $\left\langle X_{1} \ldots X_{i} \ldots X_{n}\right\rangle$, where some $X_{i}$ is associated with phonetic content, $X_{i}$ must be pronounced.

In the standard cases, (11) ensures that at least one copy in a movement chain of non-empty elements is pronounced simply because all copies in such a chain have 
phonetic content themselves that would be irrecoverably lost if they were all deleted. ${ }^{4}$ Now the key to both spell-out of the highest copy and spell-out of multiple copies as in verb doubling is what it means for a copy to be "associated with phonetic content". Landau (2006) proposes the following definition (12).

$X$ is associated with phonetic content iff:

a. $X$ has phonetic content, or

b. $X$ is in a position specified with some phonological requirement.

The crucial part of (12) is the second clause. According to Landau, certain syntactic positions can impose phonological requirements on the elements in these positions. One example is head movement of $\mathrm{V}$ to $\mathrm{T}$, where $\mathrm{V}$ adjoins to $\mathrm{T}$ and has the phonological requirement to provide a lexical host for the tense (or other) affixes in $\mathrm{T}$, an idea that, as Landau acknowledges, is not new (see Davis and Prince 1986; Dekydspotter 1992; Abels 2001).

In this case, according to clause b. of (12), $\mathrm{V}$ is associated with phonetic content and therefore will be pronounced. The lower copy of the V-movement chain can be recovered from the higher copy and does not fulfill a specific phonological requirement in its position.

The situation is different with multiple copy spell-out. Based on data from Hebrew $\mathrm{V}(\mathrm{P})$ fronting, Landau claims that in verb doubling structures, the two overtly realized copies each fulfill a distinct phonological requirement. The position adjoined to $\mathrm{T}$ is associated with the phonological requirement of providing a lexical host for tense and agreement features. The position SpecTopP imposes a phonological requirement on $\mathrm{V}$ as the head of VP, namely, the specific intonational pattern of fronted VPs. This pattern consists of a high pitch accent on the stressed syllable of the fronted verb followed by a low tone plateau (Landau 2006, 39). Consequently, both the V copy in SpecTopP and the one in $\mathrm{T}$ fulfill some phonological requirement that is not recoverable from any of the other copies and, hence, they are both unaffected by deletion.

In summary, one prerequisite of double pronunciation is that the verb moves at least twice in order for there to be two different target positions with different additional phonological demands because the verb's base position does not have any such requirements. Commonly, one of these movements is V-to-Asp/T/C movement.

Turning to Germanic, the position adjoined to $\mathrm{C}$ probably is associated with some phonological requirement demanding the overt pronunciation of the verb in second position, as most Germanic languages are V2 languages. Even when V-to-C movement does not take place, i.e. in VP-topicalizations, a dummy verb has to be inserted to fulfill this requirement. The phonological requirement fulfilled by the fronted VP is not immediately evident. One could thus expect the V copy inside the fronted VP to go unpronounced due to (10) since P-recoverability is provided by the $\mathrm{V}$ copy in $\mathrm{C}$. However, this would predict that VP-topicalization in Germanic should look just like regular object topicalization, which is clearly not the case. Landau's (2006) account thus does not straightforwardly extend to Germanic VP-topicalization.

\footnotetext{
4 Note that this requires syntactic terminals to either start out with phonological information specified or be equipped with it (e.g., via Vocabulary Insertion in Distributed Morphology) prior to the application of the deletion operation.
} 


\subsection{Parallel chains (Aboh and Dyakonova 2009)}

In a similar vein, Aboh (2006), Aboh and Dyakonova (2009), Kandybowicz (2008), and Kandybowicz and Torrence (2016) argue that the verb in verb doubling contexts undergoes two separate movements into distinct positions. The two movement dependencies have a separate head but a common tail in the base position of the verb. The two chains are reduced regularly; that is, the lower copy is deleted while the highest one of each chain is pronounced, resulting in double spell-out of the verb. This is an instance of Chomsky's (2008) parallel chains, where the lowest copy of a moved element is part of both an $\bar{A}$-chain and an A-chain. The proposals by Aboh (2006), Aboh and Dyakonova (2009), and Kandybowicz (2008) differ from Chomsky's original one in that at least one of the two parallel movements is head movement. Working on Nupe, Kandybowicz (2008) argues that the verb root $\bar{A}$-head moves into SpecFocP. Independent of this verb fronting, the verb root has to move to $v$ in the language (Kandybowicz 2008, chap. 2). Since both Foc and $v$ separately probe for the verb root, two parallel chains are created, one being a regular head movement (HM) chain and the other being an $\overline{\mathrm{A}}$-head movement ( $\overline{\mathrm{A}} \mathrm{HM}$ ) chain (13).

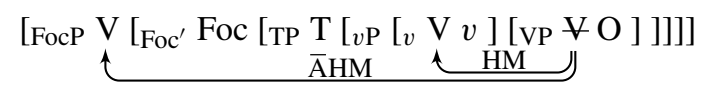

An ordinary mechanism of chain reduction then inspects each chain separately and deletes its lower copy. 5

Aboh and Dyakonova investigate VP fronting in Russian and V fronting in Gungbe. They propose that Agree-Tense-Aspect features on an Asp head (which, working under Rizzi's (1997) Split-C hypothesis, they assume are inherited from Fin) trigger the short V-to-Asp head movement. The Foc or Top head, on the other hand, bears a discourserelated feature probing for a focus feature on $\mathrm{V}$ and triggering $\mathrm{V}$-to-Foc head movement (14) (for details see Aboh and Dyakonova 2009, §4). ${ }^{6}$

$$
\text { [FocP [Foc V Foc ] [TP T [AspP [Asp } \underbrace{\mathrm{V}}_{\mathrm{HM}_{2}} \underbrace{\operatorname{Asp}}_{\mathrm{HM}_{1}}[\mathrm{VP} \underset{\mathrm{H}}{\forall} \mathrm{O}]]]]
$$

\footnotetext{
5 Kandybowicz (2008) claims that a linearization conflict (which is the trigger for deletion of all but one copy in Nunes 2004) between the two non-distinct elements in the heads of the separate chains does not arise because the lower chain between $\mathrm{V}$ and $v$ is entirely contained within the $v \mathrm{P}$ phase. In cyclic phase-based spell-out, this chain will pass the interfaces and thus undergo Chain Reduction and Linerization before the V-to-SpecFocP chain becomes available at PF. However, in standard conceptions of phase transfer, the phase head itself, $v$ in this case, is not part of the domain that is sent off to PF. As $v$ contains the higher chain link of the V-to- $v$ chain, we would expect it to not be visible by Chain Reduction and therefore, the lower link of that chain should not be deleted. Instead, upon transfer of the domain of the CP phase, both the V copy in SpecFocP and the lower one in the complex $v$ head become available at $\mathrm{PF}$ and should cause a linearization conflict that should result in the deletion of the $\mathrm{V}$ copy in $v$, contrary to fact.

$6 \mathrm{VP} / v \mathrm{P}$ movement is supposed to be the result of Generalized Pied-piping (Chomsky 1995, 262) where the whole $\mathrm{VP} / v \mathrm{P}$ moves instead of the $\mathrm{V}$ head and lands in SpecFocP/SpecTopP instead of adjoining to Foc/Top.
} 
Since, again, Foc and Asp probe separately, two distinct movement chains exist which will undergo regular chain reduction deleting the common tail of both but leaving their respective heads to be pronounced.

In summary, verb doubling is due to the fact that there are two distinct chains of verb (head-)movement, one to SpecFocP (Kandybowicz 2008) or to Foc/Top (Aboh and Dyakonova 2009) and the other to v/Asp, which are both rooted in the same position, namely the verb's base position. Whatever the mechanism is that ensures that in the common cases only the highest copy of a chain is pronounced, it also applies to these verb chains and deletes the lower copies while retaining the highest one in a regular fashion. Consequently, two copies of the verb are phonetically realized. Therefore, like in Landau (2006), verb doubling is contingent on the verb moving to some higher functional head like $v$ or Asp (or T) in addition to its displacement into the left periphery.

Turning to Germanic, as C attracts both a V head and a VP phrase, it is the case that there are two different chains, a head-movement chain and a phrasal movement chain. Of these the respective higher copies should be retained, the $\mathrm{V}$ adjoined to $\mathrm{C}$ and the VP in SpecCP, resulting in verb doubling. The parallel chains account thus does not straightforwardly extend to the Germanic pattern.

\subsection{Non-syntactic head movement (LaCara 2016a)}

The most recent proposal that is concerned with verb doubling in verbal fronting constructions is LaCara (2016a). He suggests that one can straightforwardly derive verb doubling if one abandons the idea that head movement is successive syntactic adjunction of a head to a higher head (see, e.g., Travis 1984; Pollock 1989; Vikner 1995). Concretely, he adopts the view of head movement as Conflation (Hale and Keyser 2002; Harley 2004, 2013) where the features $\mu_{\mathrm{X}}$ of a head $\mathrm{X}$ that trigger lexical insertion come to be present on higher heads under certain conditions. Due to economy considerations, insertion of actual morphemes in the presence of more than one head with the features to be expressed then only takes place in the highest head that contains them. Head movement is therefore not treated as actual displacement of a syntactic terminal but rather as a kind of feature propagation, where all the features of a lower head are also present on any higher head within a certain domain.

As a consequence, there is only one syntactic movement that leads to the creation of verb copies, namely movement of the verb phrase to SpecCP, to which a copy deletion mechanism applies in a regular fashion, deleting all but the highest copy. Crucially, if a language shows independent V-to-T movement, the verb's insertion-triggering features $\mu_{\mathrm{V}}$ are passed up to $\mathrm{T}$ by Conflation. Therefore, besides being spelled out as part of the verb phrase occupying SpecCP, the verb will also 
be pronounced in $\mathrm{T}$ despite there not being an actual $\mathrm{V}$ head in this position (15).

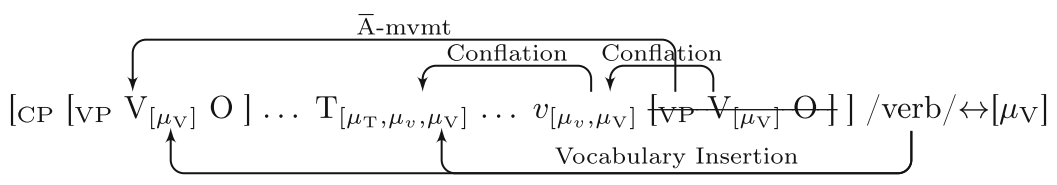

For LaCara (2016a) the pronunciation of a second verb token is independent of any actual movement or resolution mechanism as it is the regular consequence of a distinct operation, Conflation, that mimics the effects of classical head movement. Nonetheless, the core of his proposal still is the idea that also underlies the parallel chains accounts (Aboh 2006; Aboh and Dyakonova 2009; Kandybowicz 2008) and to some extent Landau's (2006) P-recoverability approach: The verb undergoes two movements whose final landing sites are pronounced. LaCara (2016a) differs only in the implementation of the second (shorter) movement step, thereby circumventing several open issues about copy deletion that were left unresolved in the other accounts. However, he ties double pronunciation to V-to- $v / \mathrm{T}$ movement just as those did.

Turning to Germanic, this account, like the two previous ones, does not straightforwardly extend to the lack of verb doubling. This is because V-to-C movement, like V-to-T movement, should propagate V's $\mu_{\mathrm{V}}$ features out of the lower VP copy. Therefore, they should evade copy deletion, resulting in the verb being spelled out twice, once in the VP copy occupying SpecCP and once in C, which (after conflation has taken place) is the highest head containing the verb's $\mu_{\mathrm{V}}$ features.

\section{The lack of verb doubling in Germanic}

In the previous section, five analyses of verb doubling in VP-topicalization constructions were discussed. In all five approaches, the overt pronunciation of the lower verb copy is due to it having combined with a higher functional head (either via headmovement or via Conflation). Therefore, generalizing from these language-specific accounts, we can identify two independent general components of verb doubling: (i) some displacement of a verbal constituent into the left periphery triggered by a functional head and (ii) head movement of $\mathrm{V}$ triggered by a functional head outside the verbal constituent.

Indeed, this correctly predicts the uniform absence of verb doubling when one of the two conditions is not met. In particular, when V-raising is blocked for whatever reason, no verb doubling should occur. This is the case, for example, when the functional head targeted by V-raising is occupied by an auxiliary as in (15).

a. [vP Wypić herbatę $]_{1}$ (to) Marek chce drink.INF tea

TO Marek wants 1 , ale nie chce jej robić. but not wants it make 'As for drinking tea, Marek wants to drink it, but he doesn't want to make it.'

(Polish, Joanna Zaleska, p.c.) 
b. [vP Liknot et ha-sefer ] 1 Dan kiva -1 . buy.INF ACC DEF-book Dan hoped

'As for buying the book, Dan hoped to do it.'

(Hebrew, Trinh 2011, 32)

As expected, the Germanic languages (illustrated by German and Norwegian below) also lack verb doubling in the presence of an auxiliary or modal as this occupies $\mathrm{C}$ and blocks V-to-C-movement of the main verb (17).

a. [vp Lange Dissertationen lesen $\quad]_{1}$ will doch heute niemand mehr _ long dissertations read.INF wants $\mathrm{PRT}$ todayno.one more 'As for reading long dissertations, no-one wants to do it anymore.'

(German)

b. [vP $(\AA)$ lese bok-en $]_{1}$ vil hun i dag __ 1 .

to read.INF book-DEF wants she in day

'As for reading the book, she wants to do it today.'

(Norwegian)

What is peculiar about Germanic is the lack of verb doubling even when an auxiliary or modal which could block V-to-C-movement is absent.

a. [vP Lange Dissertationen lesen ] tut doch heute niemand mehr. long dissertations read.INF does PRT todayno.one more

'As for reading long dissertations, no-one wants to do it anymore.'

b. [vp Haar verraden ] doet hij niet.

(German) her betray does he not

'He doesn't betray her.' (Dutch, Broekhuis and Corver 2015, 1043)

c. [VP $(\AA)$ lese bok-en ] gjør hun i dag.

to read.INF book-DEF does she in day

'As for reading the book, she does it today.'

d. ...og [vp kørde/køre bilen ] gjorde han. and droveldrive car.DEF did he

'... and drive the car, he did.'

(Norwegian)

e. [vP Läser boken ] gör han nu.

reads book.DEF does he now

'Reading the book he is now.' (Swedish, Källgren and Prince 1989, 47)

f. John wanted to read the article and [vP read the article ] he did.

The Germanic languages show both components of verb doubling. They generally make use of some displacement operation of a verbal constituent into the left periphery of the clause, namely VP-topicalization. As is well known, with the exception of English, all of them also exhibit an independent head-movement operation of $\mathrm{V}$ out of VP to some higher functional head, namely V-to-C movement (at least in matrix clauses, Vikner 1995). All else being equal, we would therefore expect them to show verb doubling, provided that $\mathrm{V}$-to- $\mathrm{C}$ movement is essentially equivalent to $\mathrm{V}$-to-Asp/ $\mathrm{T}$ movement (19). 


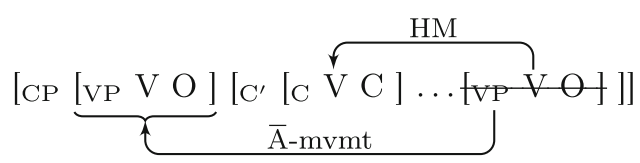

Yet, Germanic VP-topicalization does not result in verb doubling. Rather, a dummy verb takes the place of the finite verb clause-internally. Thus, $\mathrm{V}$-to-C movement must be blocked in a similar way that V-to-T/Asp/C movement is blocked when T/Asp/C is occupied by an auxiliary or modal. The question for Germanic, however, is why V-to-C-raising should be blocked in the absence of any auxiliary. To put it differently, why does VP-topicalization require the presence of a (dummy) auxiliary tun, doen, göra, gфre, gjфre?

In the following, I will first briefly present and discuss a parallel pattern found with verb-stranding VP-ellipsis. After a short digression about the locus of head movement in grammar, I will go on to discuss and reject some conceivable explanations for the peculiar Germanic behaviour involving the claims that (i) VP-topicalization is always derived from a presumed base construction where the dummy verb is independently present (thus explaining the blocking effect), (ii) there is no $\mathrm{V}$-to-C movement at all, (iii) topicalization is not ( $\overline{\mathrm{A}}-$-)movement (i.e., not triggered by a functional head), (iv) the dummy verb is a proform in a left-dislocation structure, and (v) the $\mathrm{C}$ head comes too late to trigger the relevant head movement.

\subsection{An intriguingly parallel pattern}

Interestingly, we find a strikingly similar peculiarity in the realm of VP ellipsis. In a number of languages, including (Brazilian and European) Portuguese, Hebrew ${ }^{7}$ and Russian, it is possible to pronounce the verb of an otherwise elided VP as shown in (20).

(20) a. A Joana não deu o presente à mãe, mas a prima deu <o the Joana NEG gave the present to.the mother but the cousin gave the presente à mãe $\rangle$. present to.the mother

'Joana didn't give the present to her mother but her cousin did.'

(Portuguese, Santos 2009, 22)

b. A: Šalaxt etmol et ha-yeladim le-beit-ha-sefer? send.PST.2SG.FEM yesterday ACC the-children to-house-the-book 'Did you send the children to school yesterday?'

B: Šalaxti 〈etmol et ha-yeladim le-beit-ha-sefer〉. send.PST.1SG yesterday ACC the-children to-house-the-book 'I did.'

(Hebrew, Doron 1999, 129)

c. A: Ty položil ručku na stol, ili knigu na stul? you put.PST.SG.M pen. ACC on table or book.ACC on chair 'Did you put the pen on the table or the book on the chair?'

\footnotetext{
${ }^{7}$ Note that Landau (2018) argues that examples such as (20b) are actually better analysed as involving argument ellipsis (see also footnote 15).
} 
B: Net, ne položil 〈ručku na stol, ili knigu na stul〉.

no NEG put.PST.SG.M

'No, I didn't (put the pen on the table or the book on the chair)'

(Russian, Gribanova 2013, 152)

This phenomenon is commonly referred to as verb-stranding VP-ellipsis (VVPE). It has generally received a very similar analysis to the verb-doubling VP-topicalizations (VVPT), namely, that independently attested V-raising moves the verb out of the VP before ellipsis takes place (Goldberg 2005).

$$
\ldots \mathrm{V} \ldots[\mathrm{CP} \ldots \underbrace{\mathrm{V}+\mathrm{T} / \mathrm{Asp} \ldots\langle[\mathrm{vP}}_{(1)} \mathrm{V} \mathrm{O}]\rangle(2)]
$$

As Goldberg (2005) states, all else being equal, we would expect any language that allows VPE and makes use of some independent V-out-of-VP-raising to exhibit VVPE. Curiously, Danish, Norwegian, and Swedish (Mainland Scandinavian, MSc) do not fulfill this expectation. They do allow VPE (22), and dispose of V-raising out of VP, but crucially disallow VVPE (23). ${ }^{8}$ Instead of a copy of the lexical verb, a finite form of the dummy verb gфre, gjøre, göra 'do' is pronounced.

a. Mona og Jasper havde vask-et bilen, eller rettere Mona

Mona and Jasper have.PST wash-PTCP car.DEF or rather Mona

havde $\langle\mathrm{VP}\rangle$.

have.PST

'Mona and Jasper had washed the car, or rather Mona had.'

(Danish, Sailor 2018, 855)

b. Jan kan løse problemet, men Kari kan ikke $\langle\mathrm{VP}\rangle$.

Jan can solve problem.the but Kari can not

'Jan can solve the problem, but Kari can't.'

(Norwegian, Bentzen et al. 2013, 99)

c. Johan har inte läst Lolita, men Kalle har $\langle\mathrm{VP}\rangle$.

Johan has not read Lolita but Carl has

'Johan hasn't read Lolita, but Carl has.' ～(Swedish, Thoms 2012, 7)

(23) a. Mona og Jasper vaskede bilen, eller rettere Mona gjorde.

Mona and Jasper wash.PST car.DEF or rather Mona do.PST

'Mona and Jasper washed the car, or rather Mona did.'

(Danish, Houser et al. 2011, 249)

b. Johan leste ikke Lolita, men Marie gjorde. ${ }^{9}$

Johan read.PST not Lolita but Maria do.PST

'Johan didn't read Lolita, but Marie did.' (Norwegian, Thoms 2012, 7)

c. Maria körde inte bilen, men Johan gjorde det. ${ }^{10}$

Maria drive.PST not car.DEF but Johan do.PST det

'Maria didn't drive the car, but Johan did.' (Swedish, Sailor 2018, 856)

\footnotetext{
8 At least for Norwegian and Swedish, VPE requires polarity focus (Thoms 2012,8) in contrast to English. German and Dutch are not discussed here as they do not show the necessary VPE in the first place.
} 
This intriguingly parallel lack of VVPE in MSc has been noted by Sailor (2018). He argues that it derives from the difference in the height of V-raising. While it targets $\mathrm{T}$ or Asp in the languages that show VVPE, it targets the higher C head in MSc. He adopts the theory of ellipsis of Aelbrecht (2010), where the ellipsis site essentially becomes opaque for any syntactic operations after the licensor of ellipsis, which is $\mathrm{T}$ in the case of VP ellipsis, has been merged. Now, if $\mathrm{T}$ licenses ellipsis and also triggers V-raising, both operations are assumed to take place simultaneously, resulting in a structure where the verb has moved out of the (to-be-)elided VP (24). This gives rise to verb-stranding VP-ellipsis on the surface.

$$
\text { T merges: [TP } \underbrace{\mathrm{V}+\mathrm{T}_{[\mathrm{V} * \mathrm{E}]}}\langle[\mathrm{VP} \mathrm{V} \text { O ] }\rangle \text { (1) ] }
$$

However, if the trigger for V-raising only enters the derivation after ellipsis has been licensed, the ellipsis site has already become opaque and V-raising out of it may not take place anymore. This is the case in MSc, where the trigger for $\mathrm{V}$-raising is located on $\mathrm{C}$ whereas the licensor of ellipsis is $\mathrm{T}$ (25). This derivation gives rise to a lack of VVPE in MSc.

$$
\begin{array}{ll}
\text { T merges: } & {\left[\mathrm{TP} \mathrm{T}_{[\mathrm{E}]}\langle[\mathrm{VP} \mathrm{V} \mathrm{O}]\rangle(1)\right]} \\
\text { C merges: } & \left.\left.\left.[\mathrm{CP} \underbrace{\mathrm{C}_{\left[\mathrm{V}^{*}\right]}\left[\mathrm{TP} \mathrm{T}_{[\mathrm{E}]}\langle[\mathrm{VP}\right.} \mathrm{V} \mathrm{O}]\right\rangle\right]\right]
\end{array}
$$

Effectively, Sailor (2018) makes it possible for both head movement and ellipsis to interact in both a bleeding and a counter-bleeding way by placing them both within syntax proper. The different order of application then falls out from the independent property of a language showing V-to-T or V-to-C movement. In Sect. 3.7, I argue that it is not straightforwardly possible to similarly place the copy deletion operation inside syntax proper. Nonetheless, the analysis that I put forward in this paper (see Sect. 4) ultimately also derives the presence vs. absence of VVPT from the relative distribution of the triggers for V-raising and copy deletion but in a different way than Sailor (2018).

\subsection{Short digression: the locus of head movement in grammar}

Recently, the discussion about the locus of head movement has been gaining traction again (Schoorlemmer 2012; Schoorlemmer and Temmerman 2012; Platzack 2013; Zwart 2017; Harizanov and Gribanova 2019). One proposal to reconcile both sides of the argument comes from Harizanov and Gribanova (2019). They argue that head

\footnotetext{
9 Note that the Norwegian example in this form is only accepted by some speakers. For the others, the pronoun det necessarily has to follow the dummy verb as in (i).
}

(i) Johan leste ikke Lolita, men Marie gjorde det. Johan read.PST not Lolita but Maria do.PST it 'Johan didn't read Lolita, but Marie did.'

For those speakers that allow the pronoun-less version, a version with the pronoun present is optionally possible.

10 See Bentzen et al. (2013) for arguments that göra det behaves like VPE despite the presence of det. 
movement is not a unitary phenomenon, but rather falls into two types of movement with different properties. The first kind is proper syntactic head movement which shows semantic effects, crucially influences word order and does not build morphologically complex words. The second type is postsyntactic head movement which may apply downwards (Lowering, Embick and Noyer 2001) or upwards (Raising). This type has no semantic effects and is involved in the build-up of morphologically complex words. Crucially, Harizanov and Gribanova (2019) take V-to-C movement to be of the former kind, i.e. taking place in syntax, while V-to-T/Asp movement is regarded as being of the latter, post-syntactic kind. Considering the patterns of interaction of these two kinds of V-raising with copy deletion on the one side and ellipsis on the other, we find that V-to-T movement (as in Hebrew, Portuguese, and Russian) counter-bleeds both copy deletion and ellipsis, whereas V-to-C movement (as in Danish, Norwegian, and Swedish) seems to be bled by those operations. Under the common assumption that ellipsis and copy deletion are post-syntactic operations, Harizanov and Gribanova's proposal cannot be upheld. If V-to-C movement is really syntactic, we would expect it to always apply before ellipsis and copy deletion, giving rise to both verb-stranding VP ellipsis and verb-doubling VP-topicalization, contrary to fact. Similarly, if V-to-T movement is post-syntactic, we would expect it to be possible that at least in some V-to-T languages ellipsis and copy deletion may bleed V-raising.

\subsection{The dummy verb is not independently present}

Coming back to the main topic, one immediate explanation for the lack of verb doubling and the presence of a dummy verb in Germanic VP-topicalization is that it is derived from an independent construction that already contains the dummy verb in an auxiliary position. Thus, when the VP undergoes topicalization, the dummy verb is stranded like any other tense auxiliary or modal verb and V-to-C movement is blocked by this dummy verb.

Indeed, such an independent construction, the so-called tun-periphrase, is attested in German. In colloquial German and many dialects it is possible to have the main lexical verb stay in-situ while an inflected form of the dummy verb tun 'do' acts as the finite verb occupying the final position in embedded sentences (26a) and the second position in matrix sentences (26b) (for details see Abraham and Fischer 1998; Schwarz 2009; Weber 2017).

a. Ich glaube, dass der Klaus gerade den Müll hinunter tragen tut.

I believe that the Klaus now the garbage down carry does

'I believe that Klaus is right now carrying down the garbage.'

b. Der Klaus tut gerade den Müll hinunter tragen.

the Klaus does now the garbage down carry

'Klaus is right now carrying down the garbage.'

(German, Bayer 2008, 4)

One could easily conceive of a derivation where the VP den Müll hinunter tragen is $\overline{\mathrm{A}}$ moved into SpecCP (instead of the subject Klaus) giving rise to the VP-topicalization 
sentence in (27). In fact, this is probably the correct analysis of dummy verbs in Welsh VP-topicalizations (see Sect. 5.4).

\section{[Den Müll hinunter tragen] tut Klaus gerade.}

the garbage down carry does Klaus now

'As for carrying down the garbage, Klaus is doing it right now.'

(German)

However, there are two problems with this approach for Germanic languages. First, not all of them have an analogue of the tun-periphrase. In Norwegian, for instance, a sentence corresponding to (26b) is ungrammatical (28).

(28) *Jeg gjør aldri spille golf.

I do never play golf

Intended: 'I never play golf.'

(Norwegian, Lødrup 1990, 9)

At least for languages that do not have such an independent dummy verb construction, we would still be left to explain why they do not show verb doubling.

Second, as Bayer (2008) notes, even the tun-periphrase in German is restricted to stage-level predicates. Individual-level predicates like besitzen 'own' or ähneln 'resemble' are exempt from occuring in the complement of tun 'do' (29) (also see Freitag 2019; Bayer and Freitag to appear).

a. *Der Klaus tut einen guten Charakter besitzen.

the Klaus does a good character own

'Klaus has good character.'

b. *Der Klaus tut seinem Vater ähneln.

the Klaus does his father resemble

'Klaus resembles his father.'

(German, Bayer 2008, 4)

Nevertheless, note that when individual-level predicates undergo VP-topicalization, a form of tun occurs clause-internally rather than a copy of the verb, and the sentence is grammatical (30).

(30) a. [Einen guten Charakter besitzen] tut Klaus nicht erst seit er im a good character own does Klaus not first since he in.the Internat war.

boarding.school was

'As for having good character, Klaus has had it long before he went to boarding school.'

b. [Seinem Vater ähneln] tut Klaus aber wirklich kein bisschen.

his father resemble does Klaus but really not.a little

'As for resembling his father, Klaus does not even resemble him the tiniest bit.'

(German)

Thus, even in German the tun-periphrase cannot act as a derivational base for all cases of VP-topicalization which lack the a priori expected verb doubling.

In summary, even though a construction where the dummy verb is independently present may serve as the base for some cases of VP-topicalization with a dummy verb 
in some languages, it is far from being a satisfactory account of the general lack of verb doubling in Germanic. In what follows I will thus treat the forms of tun 'do' that occur in German VP-topicalizations on a par with the dummy verb in other Germanic languages, namely as a sort of Last Resort repair to a structure that would otherwise be left without a finite verb.

\subsection{V-to-C movement takes place}

Another logically possible explanation for the lack of verb doubling in Germanic VPtopicalization concerns, of course, the second movement step that is fundamental to the above approaches to verb doubling, head movement of V out of VP. In the case of Germanic, this movement is V-to-C movement. If, for some reason, the verb were to not move to $\mathrm{C}$, it would not leave the low VP copy. When copy deletion then applied, it would delete the verb as part of the low VP copy.

This explanation is considered here only as a logical complement to the one in the previous section. Although the status of V-to-T movement is notoriously unclear for the Germanic languages (modulo English), at least since Vikner (1995) it is well established that they all (modulo English) exhibit V-to-C movement in matrix clauses.

In matrix clauses, the finite verb (bold faced) always appears in the second position in the clause preceding adverbs or negation (italicized) (31) while it follows them in embedded clauses (32).

(31) a. Peter drikker ofte kaffe om morgenen.

Peter drinks often coffee in morning.DEF

'Peter often drinks coffee in the morning.' (Danish, Vikner 1995, 47)

b. Hanne liker ikke kaffe.

Hanne likes not coffee

'Hanne doesn't like coffee.'

(Norwegian)

c. Jag kysste henne inte

I kissed her not

'I didn't kiss her.'

(Swedish, Holmberg 1999, 1)

d. Sie mag diesen Kuchen nicht.

she likes this cake not

'She doesn't like this cake.'

(German)

(32) a. Vi ved [at Peter ofte drikker kaffe om morgenen].

we know that Peter often drinks coffee in morning

'We know that Peter often drinks coffe in the morning.'

(Danish, Vikner 1995, 47)

b. Jeg tror [at Hanne ikke liker kaffe].

I believe that Hanne not likes coffee

'I believe that Hanne doesn't like coffee.'

(Norwegian)

c. ... [att jeg inte kysste henne].

that I not kissed her

'...that I didn't kiss her.'

(Swedish, Holmberg 1999, 1) 
d. Ich glaube, [dass sie diesen Kuchen nicht mag]

I believe that she this cake not likes

'I believe that she doesn't like this cake.'

(German)

Vikner's (1995) analysis (the current standard analysis) of this word order variation between matrix and embedded clauses is that while the latter show the verb in its base position inside the VP, the former involve head movement of the verb across any intervening adverbs like negation to C (see also Koster 1975; den Besten 1983; usually assumed to proceed via V-to-T movement in accordance with the Head Movement Constraint, Travis 1984). There have, of course, been arguments from single languages or language groups challenging various details of his proposal, among them arguments that Danish subject-initial clauses are TPs and the verb thus only moves as high as T (Mikkelsen 2010), debates whether V-to-T movement in the Scandinavian languages is contingent on a V2 structure (Wiklund et al. 2007), and doubts that a T head exists at all in German (Haider 2010). Nonetheless, the general consensus still is that the word order change between matrix and embedded clauses in Germanic is due to V-to-C movement in the former and its absence in the latter. The lack of verb doubling with VP-topicalization in Germanic can therefore not be attributed to the absence of head movement of the verb out of VP.

\subsection{VP-topicalization is $\bar{A}$-movement}

Yet another possible explanation for the lack of verb doubling with VP-topicalization in Germanic is that VP-topicalization does not involve movement. If the clause-initial VP were base generated in its surface position with the dummy verb being a kind of coreferential item, there is no need for movement of any kind (cf. Lumsden and Lefebvre 1990; Lumsden 1990; Larson and Lefebvre 1991; Dekydspotter 1992; Cable 2004). Without VP-movement there are no copies of $\mathrm{V}$ to be exceptionally pronounced, hence no verb doubling would occur.

Unfortunately, standard $\overline{\mathrm{A}}$-movement diagnostics like islands and long-distance extraction are not necessarily decisive on the question at hand. This is because islands usually test for extraction out of an embedded finite clause, which leaves the possibility that the VP has been base generated in the left periphery of this clause. That is, they usually test for movement out of a clause, but our question is concerned with movement inside a single clause. Some more reliable tests for this kind of movement come from reconstruction effects and extractions from coordinate structures.

With the former, the moved VP shows binding effects associated with its base position. Concretely, an anaphor in object position will still be interpreted as being bound by the subject although it has been displaced as part of the VP. This reconstruction for Principle A is shown to hold in German (33a) and Norwegian (34a). A referential expression in the topicalized VP, on the other hand, will be unable to be coreferential with a pronominal item in the subject position because it will be interpreted in the base position where such coreferentiality would constitute a Principle C violation. This is shown to be the case for German (33b) and Norwegian (34b). 
(33) a. [Sich selbst $t_{\mathrm{i}}$ loben] tut Anja $a_{\mathrm{i}}$ normalerweise nicht. REFL self praise does Anja normally not

'Praise herself, Anja usually doesn't.'

b. *[Fotos von Anja $a_{\mathrm{i}}$ mögen $]$ tut sie $_{\mathrm{i}}$ oft nicht. photos of Anja like does she often not

'Like photos of Anja, she often doesn't.'

(German)

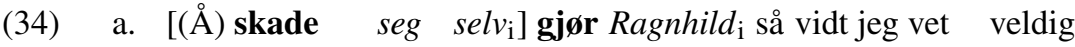
to injure.INF REFL self does Ragnhild sofar I know really sjelden.

seldom

'Hurt herself, Ragnhild only rarely does as far as I know.'

b. *[( $\AA$ ) beundre bilder av Nils $\left.s_{\mathrm{i}}\right]$ gjør $h a n_{\mathrm{i}}$ egentlig aldri.

to admire pictures of Nils does he actually never

'Admire pictures of Nils, he actually never does.'

(Norwegian)

We also find both weak (a. examples) and strong (b. examples) cross-over effects in both languages as evidenced by (35) and (36).

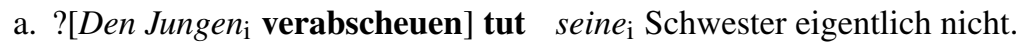
the boy loathe.INF doeshis sister actually not 'Loathe the boy, his sister actually doesn't.'

b. *[Den Jungen $n_{\mathrm{i}}$ verabscheuen $]$ tut $e r_{\mathrm{i}}$ eigentlich nicht the boy loathe.INF doeshe actually not

'Loathe the boy, he actually doesn't.'

(German)

(36) a.??[( $\AA$ ) hate gutten $\left._{\mathrm{i}}\right]$ gjør hans $\mathrm{i}_{\mathrm{i}}$ søster egentlig ikke.

to hate.INF boy.DEF does his sister actually not

'Hate the boy, his sister actually doesn't.'

b. *[(̊) hate gutten $\mathrm{i}]$ gjør han $_{\mathrm{i}}$ egentlig ikke.

to hate.INF boy.DEF does he actually not

'Hate the boy, he actually doesn't.'

(Norwegian)

With regard to extraction from coordinate structures, we find that topicalization of a single VP out of a VP conjunction structure is ungrammatical in German (37) and Norwegian (38). This follows if topicalization is actual movement violating the Coordinate Structure Constraint (Ross 1967).

*[(̊) vaske bil-en] [gjør han og rydder opp hus-et] i dag. to wash.INF car-DEF does he and tidies up house-DEF in day

'Wash the car he does and tidy up the house today.'

(Norwegian)

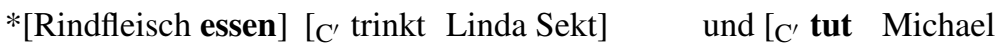
beef eat.INF drinks Linda champagne and does Michael gern]. ${ }^{11}$

gladly

'As for eating beef, Linda drinks champagne and Michael likes to do it.'

(German) 
As far as I know, VP-topicalization in other Germanic languages like Danish, Dutch, and Swedish behaves alike with regard to cross-over effects, reconstruction, and topicalization from coordinate structures.

From that I conclude that VP-topicalization is in fact ( $\overline{\mathrm{A}}-)$ movement of a VP from its base position into the left periphery rather than base generation of a VP in the left periphery.

\title{
3.6 VP-topicalization is not left dislocation
}

One last possibility to explain the lack of verb doubling in Germanic is that VPtopicalization is actually a (contrastive) left dislocation structure (Ott 2014) akin to (39).

[Den Peter], den habe ich gesehen. the.ACC Peter him. ACC have I see.PTCP 'As for Peter, I saw him.'

(German, Ott 2014, 269)

In this kind of structure, there is a left-peripheral element Den Peter, which precedes an independently grammatical clause with a resuming pronominal element den. In analogy, the topicalized VPs in (40a) and (40b) precede a clause with a dummy verb as a kind of verbal pronoun resuming them.

a. [( $(\AA)$ lese boken] gjør han $\mathrm{i}$ dag.

to read.INF book.DEF does he in day

'As for reading the book, he does it today.'

(Norwegian)

b. [Das Auto waschen] tut er nur samstags.

the car wash.INF does he only on.Saturday

'As for washing the car, he only does it on Saturdays.'

(German)

\begin{abstract}
11 Note that in contrast to the Norwegian examples, the subject in the second conjunct must be overtly distinct from the one in the first conjunct. The conjunction must therefore be between $\mathrm{C}^{\prime}$ constituents rather than VP constituents. Otherwise, the sentence could receive a structural analysis as an SLF construction (Subjectlücke in finiten Sätzen, Höhle 1983, 1990, 1991). This construction has, together with a few others from various languages, been subsumed under the term asymmetric coordination because superficially they all look like proper coordination but crucially do not show the same syntactic behaviour. Most importantly, they seem to be able to violate the Coordinate Structure Constraint. This also holds for the SLF construction, where for instance an NP can be topicalized from one of the two conjuncts without rendering the sentence ungrammatical (ia). Equally, VP-topicalization out of one conjunct in such an SLF construction results in a grammatical sentence (ib).
\end{abstract}

(i) a. Sekt trinkt Linda gern und isst dazu am liebsten Rindfleisch. champagne drinks Linda gladly and eats there.to at.the dearest beef 'Champagne, Linda likes to drink and preferably eats beef with it.'

b. [Sekt trinken] tut Linda gern und isst dazu am liebsten Rindfleisch. champagne drink. INF does Linda gladly and eats there.to at.the dearest beef 'Drinking champagne Linda likes to do and preferably eats beef with it.'

Asymmetric coordinations have been analysed as underlying subordinations that become superficial coordinations in the course of the derivation (see Weisser 2015). For an analysis of SLF constructions along these lines see Barnickel (2017). 
However, this approach is untenable for two reasons. First, note that (39) violates the V2 property of German, if both constituents Den Peter and den are parts of a single clause. The fact that (39) is still grammatical has been taken as evidence that the left-dislocated constituent is not part of the clause as its resuming element (Zaenen 1997; Ott 2014). Now, if the topicalized VP in (40) corresponds structurally to Den Peter in (39), it should also be outside of the following clause. This would leave the clause without a preverbal constituent in violation of V2. Consequently, (40) should be ungrammatical, contrary to fact (for a similar argumentation on Swedish VPtopicalization, see Källgren and Prince 1989).

Second, there are VP-left dislocation constructions in all Germanic languages which parallel the left dislocation structure in (39) even closer than the VP-topicalization in (40) does in that they also seemingly violate the $\mathrm{V} 2$ requirement of a single preverbal constituent (41).

a. [Läser boken], det gör han. reads book.DEF it does he

'Read the book, that he does.'

(Swedish, Källgren and Prince 1989, 48)

b. [Sein Auto waschen], das tut er nur samstags.

his car wash.INF that does he only on.Saturday

'Wash his car, that he only does on Saturdays.'

(German)

In these constructions, the resuming element (corresponding to den in (39)) is the pronominal det/das rather than the finite verb gjør/tut.

One could, of course, argue that VP-topicalization is derived from VP left dislocation by topic drop of det/das, which is in principle a feasible analysis. However, this account does not extend to V-topicalization, which is available in addition to VPtopicalization in Dutch and German (42). As (43) exemplifies, V left dislocation is ungrammatical (at least in German) and could thus not serve as a derivational base for V-topicalization.

(42) a. Verraden doet hij haar niet.

betray doeshe her not

'He doesn't betray her.'

(Dutch, Broekhuis and Corver 2015, 1045)

b. Waschen tut er das Auto nie. wash.INF does he the car never 'He never washes the car.'

(German, Diedrichsen 2008, 221)

(43) *Waschen, das tut er das Auto nie.

wash.INF that does he the car never

Intended: 'As for washing, he never washes the car.'

(German)

Both V- and VP-topicalization (at least in German) behave in a parallel fashion syntactially (see Hein 2018, §A.3.1.4), which strongly suggests that they share a common derivation differing only in whether the moved category is a full VP or a remnant VP. This parallelism would be neglected by the topic drop analysis of VP-topicalization. ${ }^{12}$ An account of VP-topicalization based on VP left dislocation is therefore not persua-

12 I owe this argument to Klaus Abels. 
sive. In fact, Ott (2014) presents the inverse account, which derives contrastive left dislocation from topicalization.

\subsection{V-to-C movement is not bled by spell-out of VP}

Connected to the nature of the relevant head movement in Germanic there is another seemingly elegant way to account for the difference between Germanic and other languages. In contrast to Hebrew, Polish, and many other non-Germanic verb doubling languages, the head movement that is supposedly responsible for the exceptional pronunciation of the lower V copy is V-to $\mathrm{C}$ rather than V-to-T movement. Combined with current Phase Theory (Chomsky 2000, 2001), this independent difference might make for a neat account of the lack of verb doubling. An analogous proposal has been put forward in Sailor (2018) to account for the lack of verb-stranding VP-ellipsis in Mainland Scandinavian despite showing the crucial ingredients for it independently, namely VP-ellipsis and head movement of V out of the ellipsis site (see Sect. 3.1).

Suppose that both $\mathrm{CP}$ and $v \mathrm{P}$ are phases whose domain (i.e., complement) is sent off to $\mathrm{PF}$ at a certain point of the derivation, rendering it opaque for probing and extraction. ${ }^{13}$ Suppose further that head-movement is always triggered by a head-movement feature $[\circ \mathrm{Ho}]$ on the criterial head (i.e., the goal of the head movement process). In Germanic, the triggering head would have to be $\mathrm{C}$ since $\mathrm{V} 2$ always requires $\mathrm{V}$-to- $\mathrm{C}$ movement. V-to-T only occurs as a by-product of $\mathrm{V}$-to-C due to locality constraints such as the Head Movement Constraint (Travis 1984). That is, V-to-T is never induced by T, only by C (see Vikner 1995; van Craenenbroek and Haegeman 2007). Now, if V only started moving when the movement-trigger $\mathrm{C}$ enters the structure, it should actually already be inaccessible for probing as it is properly included inside the domain of the $v \mathrm{P}$ phase (44). It should therefore regularly undergo copy deletion as part of the low VP copy, thereby explaining the lack of verb doubling. ${ }^{14}$

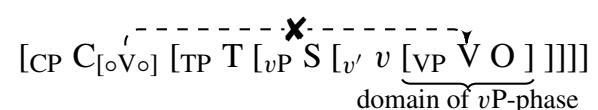

Although this proposal very elegantly derives the presence and absence of verb doubling in different languages from the interaction of an independent difference in height

\footnotetext{
13 I am not considering any of the various modifications of phase theory here, such as parameterized phases (Bošković 2014), phase extension (den Dikken 2007), or phase sliding (Gallego 2010). The conclusions might turn to out to be different for those approaches.

14 If, as is standardly assumed, V-to- $v$ movement takes place by default, $\mathrm{V}$ should be accessible to $\mathrm{C}$ as part of the edge of the phase. In order for a phase-based approach to work, one would have to adopt a Voice head that intervenes between $\mathrm{T}$ and $v$, introduces the external argument, and constitutes the actual phase head (i) (Pylkkänen 2008; Merchant 2013; Harley 2013; Legate 2014).
}

$$
\left[\mathrm{CP} \mathrm{C}_{\left[\circ \mathrm{V}_{\mathrm{o}}\right]}\left[\mathrm{TP} \mathrm{T}\left[\text { VoiceP } \mathrm{S}[\text { Voice }^{\prime} \text { Voice } \underbrace{\left.\left[{ }_{v \mathrm{P}} \mathrm{V}+v \text { [VP } \mathrm{V} \mathrm{O}\right]\right]}_{\text {domain of VoiceP-phase }}]\right]\right]\right.
$$

For expository reasons, I will abstract away from V-to- $v$ in what follows. The reader may freely substitute Voice for $v$ and $\mathrm{V}+v$ for $\mathrm{V}$ in the examples to undo the abstraction. 
of a language's V-movement with general principles of phase theory, it does not hold up to closer scrutiny as it leads to wrong predictions concerning V-to-T languages and $\mathrm{V}$-to-C languages. Two scenarios are conceivable, differing in whether the strong or the weak version of the Phase Impenetrability Condition (PIC) is taken to hold.

Under the strong PIC (Chomsky 2000), the domain of the phase becomes opaque as soon as the phase is completed. In our case, upon merge of the subject in its base position in Spec $v \mathrm{P}$, the domain of $v \mathrm{P}$ (i.e., $\mathrm{VP}$ ) would become opaque and inaccessible for probing from the outside. As both $\mathrm{T}$ (45a) and C (45b) are merged after completion of the $v \mathrm{P}$ phase, $\mathrm{V}$-attracting probes on these heads come too late to trigger head movement of $\mathrm{V}$.

$$
\begin{aligned}
& \text { a. [TP } \left.\mathrm{T}_{[\circ \mathrm{Vo}]}\left[v \mathrm{P} \mathrm{S}[v^{\prime} v \underbrace{[\mathrm{VP} \mathrm{V} \mathrm{O}]}_{\text {opaque domain }}]\right]\right] \\
& \text { b. [CP } \left.\mathrm{C}_{[\circ \mathrm{Vo}}\left[\mathrm{TP} \mathrm{T}\left[v \mathrm{P} \mathrm{S}[v^{\prime} v \underbrace{[\mathrm{VP} \mathrm{V} \mathrm{O}]}_{\text {opaque domain }}]\right]\right]\right]
\end{aligned}
$$

Therefore, both Germanic (with $\mathrm{C}$ being the $\mathrm{V}$-movement trigger) and non-Germanic languages (with $\mathrm{T}$ or Asp being the V-movement trigger) should behave alike in VPfronting contexts: Both should not exhibit verb doubling. As this is not the case, the account based on the strong version of the PIC cannot be correct.

Under the weak PIC (Chomsky 2001), the phase domain only becomes opaque upon merger of the next-higher phase head. Thus, the domain of the $v \mathrm{P}$ phase (VP) will be inaccessible for probing once the $\mathrm{C}$ head enters the structure. In this case, a head-movement trigger in T/Asp may probe for $\mathrm{V}$ inside the VP as T/Asp is merged before $\mathrm{C}$ and $\mathrm{V}$ head-moves to T/Asp (46a). However, as soon as $\mathrm{C}$ is merged, VP becomes opaque and the head-movement trigger on $\mathrm{C}$ cannot probe for $\mathrm{V}$ inside the VP (46b).

$$
\text { a. [TP } \underbrace{\left.\mathrm{V}+\mathrm{T}_{[\circ \mathrm{Vo}]}\left[v \mathrm{P} \mathrm{S}\left[v^{\prime} v[\mathrm{VP} V \mathrm{O}]\right]\right]\right]}
$$

This straightforwardly derives the occurrence of verb doubling in V-to-T/Asp languages like Hebrew and Polish but the lack thereof in V-to-C languages like the Germanic ones. Unfortunately, this approach also predicts that V-to-C movement should be blocked in all instances where $v \mathrm{P}$ (and $\mathrm{CP}$ ) is a phase. This commonly also includes regular declarative matrix clauses lacking any VP-topicalization at all. We would thus falsely expect these to not exhibit V-to-C movement, i.e. V2 word order. In order to save the account, one would have to encode the presence/absence of VP-topicalization somewhere low in the clause either by stating that $v \mathrm{P}$ is arbitrarily only a phase in sentences that show VP-topicalization or by claiming that $v$ or T act as 
exceptional V-movement triggers in clauses without VP-topicalization. In my opinion, both options equally lack independent evidence.

A further proposal where V-raising is bled by copy deletion would be to suggest that a low copy is deleted as soon as its c-commanding higher copy is generated. In the case of VP-topicalization, this would be when $\mathrm{C}$ enters the structure and attracts the VP into its specifier. Crucially, though, $\mathrm{C}$ is also the head that attracts the verbal head. Following Sailor (2018), this would mean that both V-raising and VP-topicalization (plus the associated immediate deletion of the low VP copy) take place simultaneously as has been the case for VVPE when T both attracts the verb and triggers VP-ellipsis (see Sect. 3.1, example (24)). Consequently, under this proposal we would expect Germanic V2 languages to exhibit VVPT, contrary to fact. In order to derive the lack of VVPT, one would have to postulate that although both operations are triggered by C, VP movement (and associated CD) takes place before V-movement, i.e. that the features triggering those operations are ordered on $\mathrm{C}$. While ordered features on heads have been proposed (see van Koppen 2005; Müller 2009; Halpert 2012; Georgi 2014; Assmann et al. 2015; Puškar 2018; Murphy and Puškar 2018, among others), this order has to be extrinsically determined. Furthermore, it would remain unexplained why they could not apply in the exact reverse order.

However, I think that this line of reasoning is essentially on the right track. Therefore, in the following section, I will develop a proposal where the lack of VVPT in Germanic follows from a fixed order of application between VP-movement and Vraising, which itself falls out from independent properties of the underlying structure of the clause. The proposal put forward here therefore builds on the general idea evident in Sect. 2 that verb doubling is the result of head movement plus exceptional non-deletion of the verb (see among others Abels 2001; Nunes 2004; Landau 2006; Kandybowicz 2008; Aboh and Dyakonova 2009) and that doubling is absent in case the relevant V-raising is blocked (Kandybowicz 2008; Aboh and Dyakonova 2009). What it contributes is a further configuration where this head movement is blocked and an explanation as to why it is blocked there.

\section{An explanation based on head-height}

In the preceding section, I have argued that VP-topicalization in Germanic languages is indeed ( $\overline{\mathrm{A}}$-)movement and that $\mathrm{V}$-to-C movement does take place in these languages. Thus, all necessary ingredients for verb doubling to occur are present. I have also shown that the unexpected lack of verb doubling can neither be explained by VP-topicalization being derived from a construction in which the dummy verb is independently present, nor be due to VP-topicalization being left dislocation, nor be attributed to the interaction of the head-movement-triggering heads with phase-boundaries.

In this section, I will propose an explanation based on the different height of the respective V-raising in verb doubling languages compared to Germanic languages. 


\subsection{The role of height of head movement}

As shown above, the difference between verb doubling and $d o$-support cannot be accounted for by the phase-based difference in accessibility of $\mathrm{V}$ depending on whether $\mathrm{T}$ or $\mathrm{C}$ is the attracting head. Nonetheless, the one very prominent contrast between languages like Hebrew, Polish, and many other non-Germanic languages on the one side and Germanic languages on the other side is that the head movement supposedly responsible for verb doubling is V-to-T/Asp movement in the former, but V-to-C movement in the latter. ${ }^{15}$ Thus, the general idea that the height of head movement plays a role, as in Sailor's (2018) account of VVPE, is an attractive one. It would link the occurrence of either verb doubling or $d o$-support with VP-topicalization in a language to an independent property of the language. In addition, this would be a property which is very prominent in the grammar and which is acquired quite early and consistently (Clahsen 1990/1991; Santelmann 1995; Bohnacker 1999; Blom 2003; Westergaard 2009). It thus provides an easily accessible and reliable cue for the learner as to which repair strategy the language uses in auxiliaryless VP-topicalization. Furthermore, it seems to be the case that, of the above-mentioned non-Germanic languages that show do-support in VP-fronting, many can be analysed as also exhibiting V-to-C movement in the relevant constructions (see Ortiz de Urbina 1989, 1994; Elordieta 2001; Irurtzun 2007; Duguine and Irurtzun 2014 for Basque; Schafer 1995, 1997 for Breton; Watanabe 1993 for Welsh; and Martinović 2015, 2017 for Wolof). An account in which the height of the functional head targeted by verb movement is responsible for which repair strategy occurs can straightforwardly derive this observation.

Hence, in the following, I will present a solution to the puzzle making use of this crucial difference between Germanic and non-Germanic languages. Assuming that both phrasal movement and head movement require a featural trigger on the attracting head, what sets Germanic languages apart is that the trigger for head movement of the verb is located on the same head as the trigger for phrasal $\overline{\mathrm{A}}$-movement of the verb phrase, namely the $\mathrm{C}$ head (47). In verb doubling languages, only the latter trigger is located on $\mathrm{C}$, whereas the former is located on a functional head below $\mathrm{C}$, namely $\mathrm{T}$ or Asp (48). I claim that this difference is responsible for the lack of verb doubling in Germanic.

$$
\begin{aligned}
& \text { Distribution of movement-triggering features in dummy verb languages } \\
& \mathrm{C}_{[\bullet \mathrm{VP} \bullet, \circ \mathrm{V} \circ]}, \mathrm{T}_{[]} \\
& \text {Distribution of movement-triggering features in verb doubling languages } \\
& \mathrm{C}_{[\bullet \mathrm{VP} \bullet]}, \mathrm{T}_{[\circ \mathrm{V} \circ]}
\end{aligned}
$$

\footnotetext{
15 Two anonymous reviewers note that all cited languages with verb doubling (i.e., Portuguese, Hebrew, Polish, and Russian) also allow argument drop/ellipsis whereas the Germanic languages do not. Taking up this observation, it might thus be the case that in the former, argument ellipsis is preferred over complete deletion of the low VP copy, thereby sparing the verb from non-pronunciation, in order to satisfy the constraint of having a finite verb in the clause. In the latter, this option is not available. The lower VP copy must therefore be deleted as a whole, with dummy verb insertion taking place as a repair to provide the clause with a finite verb. While this observation is indeed an interesting one which might open up a different approach to the problem at hand, for reasons of space and coherence, I will not pursue it further in this paper.
} 
In the next section, I will briefly lay out the details of the proposal and then show how the system derives Polish verb doubling and German dummy verb insertion in a VP-topicalization structure.

\subsection{Probing and lower copy freezing}

I assume that movement, be that phrasal or head movement, is triggered by a feature on the attracting head. This feature probes the c-command domain of the head looking for a goal (movement is preceded by Agree; Chomsky 1995). Upon encountering a goal, movement takes place immediately. Probing proceeds in a stepwise fashion as follows: First, the sister node XP of the probing head $\mathrm{H}$ is inspected. If no match occurs, the first daughter of XP is inspected. If again no match occurs, the second daughter of XP is inspected. This process is repeated on the level below the daughters of XP until a matching goal is found (Himmelreich 2017; for related ideas on iterative downward search see also Kitahara 1997; Müller 1998; Preminger 2019). Probing occurs as soon as the probe-bearing head is merged (Earliness; Pesetsky 1989; Řezáč 2004). Once a feature has found a goal and triggered any associated operations, it is discharged (marked by striking through).

Crucially, if $\mathrm{H}$ bears more than one probe $\mathrm{P}_{1}, \mathrm{P}_{2}$, there is still just a single run through the nodes in H's c-command domain. The difference to a situation with a single probe is that the node currently under inspection is now checked for a match with either $\mathrm{P}_{1}$ or $\mathrm{P}_{2}$ before, in case no match is found, the algorithm progresses to the next node and checks it for a match with either $\mathrm{P}_{1}$ or $\mathrm{P}_{2}$. There is thus no notion of ordering between probing for $\mathrm{P}_{1}$ and probing for $\mathrm{P}_{2}$ in the system (pace Müller 2009; Georgi 2014; Assmann et al. 2015; Puškar 2018). ${ }^{16}$

In general, there are two types of movement-triggering features, one for phrasal movement $([\bullet \mathrm{F} \bullet])$, which leads to movement of the goal into the specifier of the attracting head, and another one for head movement ([oFo]), which leads to adjunction of the goal to the attracting head. This entails that projection levels of (category) features must constitute a possible search criterion for a probe (cf. the $\left[\bullet \mathrm{F}_{2} \bullet\right]$ and $\left[\bullet F_{0} \bullet\right]$ features in Müller 2017, 2018; pace Preminger 2019; Harizanov 2019).

Working within the Copy Theory of Movement, when $\alpha$ undergoes movement, a copy of it is left behind. Since not all copies receive an overt pronunciation, there is assumed to be a post-syntactic mechanism Copy Deletion (CD) that identifies and deletes superfluous copies. Various proposals have been made as to the exact definition of this process (see, e.g., Brody 1995; Bobaljik 1995; Groat and O'Neill 1996; Pesetsky 1997, 1998; Nunes 2004). For concreteness, I will adopt Nunes' (2004) formalization here, which, roughly speaking, deletes lower copies under c-command from a higher copy in order to resolve a linearization conflict induced by the presence of more than one copy.

\footnotetext{
16 There is a second option here. Each probe could trigger its own cycle of the algorithm, resulting in two runs through the nodes in H's c-command domain. The drawback with this approach compared to the one presented in the main text is that one would have to stipulate which probe triggers its algorithm first. In the present paper, $[\bullet \mathrm{F} \bullet]$ would have to take precedence over $[\circ \mathrm{Fo}]$ in order to derive the blocking effect. No such parochial ordering is necessary if there is just a single run of the algorithm, where the blocking effect is the natural and only result.
} 
Moved constituents exhibit so-called freezing effects, meaning that elements from inside a moved constituent cannot be further extracted from that constituent (Ross 1967, 1974; Wexler and Culicover 1977, 1980; Takahashi 1994, among many others; also see Corver 2006 for a recent overview). Within the copy theory of movement, I suggest this entails that all copies of a moved constituent YP have to be frozen. If only the highest copy (the one in the final landing site) were inaccessible for subextraction $(\boldsymbol{X}$ in (49)), one would expect that a probe $\mathrm{H}$ searching for a goal XP that is part of YP could simply ignore the highest copy of XP and target the XP copy inside the lower copy of YP $(\checkmark$ in (49)). Note that this cannot be precluded by a general account of intervention effects as the goal XP in the higher copy of YP does not c-command the goal XP in the lower copy of YP and therefore does not count as an intervener (49).

$$
\begin{aligned}
& \mathrm{H}_{[\bullet \mathrm{XP} \bullet} \ldots\left[\mathrm{ZP}[\mathrm{YP} \mathrm{Y} \mathrm{XP}]\left[\mathrm{Z}^{\prime} \mathrm{Z}_{[\bullet \mathrm{YP} \bullet]} \ldots[\mathrm{YP} \mathrm{Y} \mathrm{XP}]\right]\right]
\end{aligned}
$$

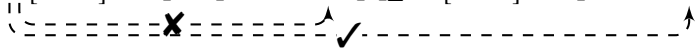

Since Agree is a necessary prerequisite for movement, the freezing condition can be formulated as a condition on Agree. I will thus assume the following formulation of a Condition on Movement-Triggering Agree (somewhat similar in spirit to Puškar's (2017) Condition on Agree Domains, albeit formulated on domination rather than c-command). ${ }^{17}$

\section{Condition on Movement-Triggering Agree (CoMTA)}

Once a probe $\mathrm{P}$ has targeted a goal $\mathrm{G}$ triggering movement of $\mathrm{G}$, a probe $\mathrm{Q}$ cannot induce movement of a constituent dominated by (any copy of) G.

We now turn to how this links verb doubling to the height of the target of verb movement.

\subsection{Deriving (the lack of) verb doubling}

The interplay between the locations of the movement-triggers, simultaneous probing, and freezing straightforwardly derives the occurrence of verb doubling in V-to-T/Asp languages and its absence in V-to-C languages (without independent V-to-T).

Concerning V-to-T languages, the trigger for $\mathrm{V}$ movement is on $\mathrm{T}$ and that for $\mathrm{VP}$ movement on $\mathrm{C}$. As $\mathrm{T}$ merges before $\mathrm{C}$, it is able to probe for the $\mathrm{V}$ head and attract it without hindrance. Only when $\mathrm{C}$ merges, is movement of the VP triggered by the $[\bullet \mathrm{VP} \bullet]-$ feature on $\mathrm{C}$ and the VP becomes frozen (indicated by boxing it). When copy deletion applies at PF, it deletes the lower VP copy. In the resulting structure, there are two copies of $\mathrm{V}$, one in the complex $\mathrm{V}+\mathrm{T}$ head and another one inside the VP in SpecCP (51).

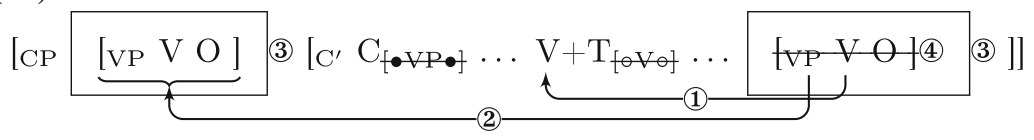

\footnotetext{
17 Preminger (2019) and Harizanov (2019), discussing clitic doubling, propose an exactly adverse scenario where an Agree relation between a probe $\mathrm{P}$ and a goal $\mathrm{G}$ is the necessary prerequisite for an otherwise precluded Agree relation between $P$ and any $\mathrm{G}^{\prime}$ that is dominated by $\mathrm{G}$. I refer the interested reader to their papers.
} 
Copy deletion does not affect the V copy in T, as it is not c-commanded by the higher $\mathrm{V}$ copy inside the VP in SpecCP. Note that the head targeted by verb movement need not necessarily be $\mathrm{T}$ in order for verb doubling to arise. It may also be Asp or Agr or any other functional head (except $\mathrm{C}$ ) provided that it is located outside the constituent that undergoes fronting to SpecCP.

Turning to V-to-C languages, both probes are located on the $\mathrm{C}$ head. As multiple probes on the same head still initiate only one cycle of the probing algorithm, in Germanic languages probing for $\mathrm{V}$ and VP starts when the $\mathrm{C}$ head is merged. Now, VP is encountered earlier by the probing algorithm than $\mathrm{V}$ and, consequently, the VP probe finds its goal first and triggers movement of VP to SpecCP, leaving a (low VP) copy. Given that the freezing effects also hold for lower copies of moved elements, the $\mathrm{V}$ probe, which encounters its goal later than the VP probe, fails to trigger V-to-C movement due to the CoMTA (49). ${ }^{18}$ Copy deletion later deletes the low VP copy and the contained $\mathrm{V}$ with it resulting in a structure which contains only one copy of the lexical verb in the VP in SpecCP. Thus, phrasal movement of VP bleeds head movement of $\mathrm{V}$ in $\mathrm{V}$-to-C languages (52).

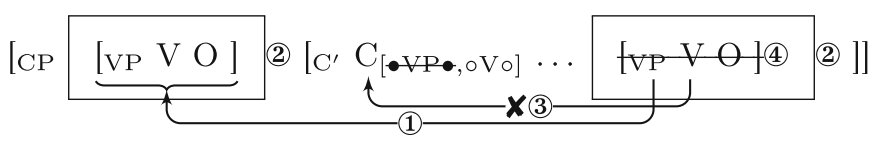

There are two crucial states of affairs in this derivation that come together to prevent the head movement: First, the constituent attracted by the head movement probe is contained inside the constituent attracted by the phrasal movement probe (53a). And, second, the head movement probe is not located on a head that is c-commanded by (i.e., lower than) the head bearing the phrasal movement probe (53b).

\section{Prerequisites for bleeding of head movement}

a. $\exists([\bullet \mathrm{YP} \bullet] \wedge[\circ \mathrm{Xo}])$, such that $\mathrm{X}$ is dominated by $\mathrm{YP}^{19}$

b. $\neg \mathrm{H}_{[\bullet \mathrm{YP} \bullet]}>\mathrm{H}_{[\circ \mathrm{X} \circ]}$, where $>$ stands for c-command

In the absence of (53b), (53a) alone is not sufficient to prevent head movement. This is the situation for VP-topicalization in V-to-T languages described in (51), where the head targeted by the head movement probe, namely $\mathrm{V}$, is dominated by the phrase targeted by the phrasal movement probe, namely VP. In this situation, verb movement is possible. Conversely, if (53b) is given, but not (53a), head movement should

\footnotetext{
18 This leaves the derivation with the [oVo] feature on C not satisfied. However, as Preminger (2011) argues, failed Agree does not necessarily lead to a crash of the derivation. Alternatively, the occurring $d o$-verb could be analysed as realizing the non-discharged [oVo] feature and thus marking the failed Agree operation overtly (see also Halpert 2012, §4.2.5, on the conjoint/disjoint alternation in Zulu for a very similar idea). The latter option entails that the dummy verb is inserted in C. However, Platzack (2008, 2012) and Bjorkman (2011) argue that it is the overt realization of $v$ (at least in the Mainland Scandinavian languages). Therefore, I adopt the former view that failed Agree is not an obstacle for convergence of a derivation.

19 For ease of exposition, I assume the phrasal probe to probe for the category VP here. In fact, the feature that this probe is looking for (especially in non-V2 languages like Polish or Hebrew) is probably an information-structural one, such as [TOPIC] or [FOCUS]. Thus, clause a. of (53) would more precisely read: $\exists([\bullet \mathrm{F} \bullet],[\circ \mathrm{X} \circ])$, such that $\mathrm{X}$ is dominated by a projection of the head bearing $[\bullet \mathrm{F} \bullet]$ and $\mathrm{F}=$ TOP or FOC.
} 
be allowed. This state of affairs is found with regular (non VP-topicalization) V2 sentences. An example from Norwegian is given in (54).

Nobelpris-en vant Einstein for sin forklaring av den fotoelektriske Nobel.Prize-DEF win.PST Einstein for his explanation of the photo-electric effekt.

effect

'Einstein won the Nobel Prize for his explanation of the photo-electric effect.'

Since Koster (1975), Thiersch (1978), and den Besten (1983), the V2 property has been standardly analysed as verb movement to the $C$ position coupled with phrasal movement of some XP into the specifier of CP. In the present framework, both of these movements are triggered by (features on) the $\mathrm{C}$ head (making (53b) true). Nonetheless, the presence of a phrasal movement feature besides a head movement probe does not and in fact must not block verb raising to $\mathrm{C}$, as this would incorrectly rule out regular V2 sentences. Consider (55), roughly representing the structure of (54), where the internal argument of a transitive verb is targeted for movement to SpecCP.

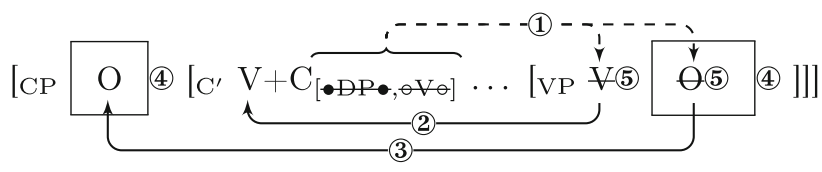

When $\mathrm{C}$ is merged, both of its probes start looking for a goal. According to the Agree algorithm, $\mathrm{V}$ is encountered first and head-moves to $\mathrm{C}$. As the object is not contained in $\mathrm{V}$ (making (53b) false), probing for [ $\bullet \mathrm{DP} \bullet$ ] continues. It eventually encounters the object DP and triggers movement to SpecCP. Thus, head movement has taken place unhindered. Note that even if the attracted DP is higher than V in the structure, as would be the case for a subject, head movement may take place. In this situation, the subject would be encountered first, triggering its movement to SpecCP. As V is not dominated by the subject, it is not frozen by subject movement and can be raised to $\mathrm{C}$ by $[\circ \mathrm{Vo}]$.

With these general conditions in place we can now turn to two example derivations of VP-topicalization, one which shows verb doubling and another which exhibits no verb doubling. Those are supposed to stand as exemplars for their respective language groups.

\subsection{Verb doubling in Polish VP-topicalization}

One of the non-Germanic languages that shows verb doubling with VP-topicalization is Polish (Bondaruk 2009, 2012). ${ }^{20}$ An example of the construction where the verb inside the fronted VP appears in the infinitive while its copy inside the clause is finite, is given in (56).

\footnotetext{
20 Bondaruk $(2009,2012)$ refers to this type of construction as a "predicate cleft", which implies a biclausal (base generation) structure. However, based on various $\overline{\mathrm{A}}$-movement diagnostics, she eventually attributes to it a monoclausal structure in which a verb phrase has moved into the left periphery.
} 
(56) [Wypić herbatę] (to) Marek wypije, ale nie wypije kawy. drink.INF tea TO Marek will.drink but not will.drink coffee 'As for drinking tea, Marek will drink it, but he will not drink coffee.'

(Polish, Bondaruk 2012, 55)

As Witkoś (1998) argues, it also exhibits verb raising to Asp. The trigger for head

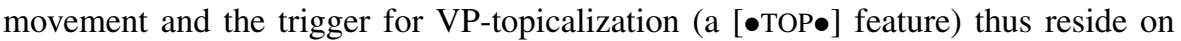
distinct heads; the former is on Asp while the latter is on $\mathrm{C}$ (assuming that SpecCP is the position for topics in Polish).

The derivation of this sentence in the current system is as follows. First, the VP is built by merge of the verb with its object. The new phrase is in turn selected by $v$, which then introduces the subject. According to Witkoś (1998), the $v \mathrm{P}$ is then merged with an Asp head which initiates probing (step (1) and triggers head movement of V (step (2)) (57).

$$
\begin{aligned}
& \text { Polish VP-topicalization: V-raising to Asp } \\
& \left.\left.\left.\left[\operatorname{AspP}^{\mathrm{V}+\mathrm{Asp}_{[\odot \mathrm{V} \theta]}\left[{ } ^ { 1 } \mathrm { P } \mathrm { S } \left[v ^ { \prime } v \left[\mathrm{VP}_{[\mathrm{TOP}]}\right.\right.\right.} \mathrm{V} \mathrm{O}\right]\right]\right]\right]
\end{aligned}
$$

Upon merger of the T head with AspP, the subject moves to SpecTP (step (3)). When C

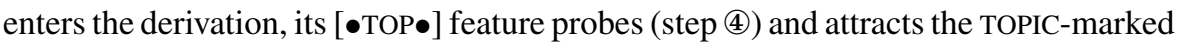
VP into its specifier (step (5), resulting in a structure like (58) with frozen VP copies (step (6). ${ }^{21}$

(58) Polish VP-topicalization: VP-to-SpecCP movement and Spell-Out

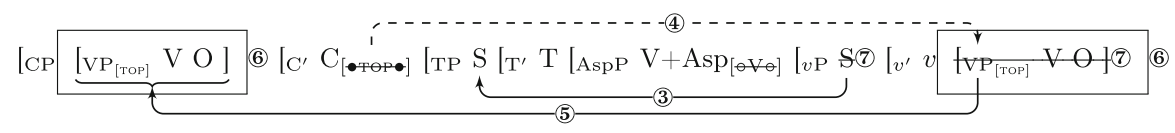

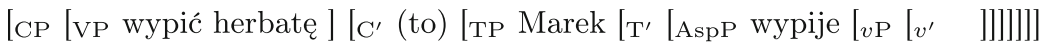
At spell-out, copy deletion (step (7) in (58)) then erases the lower subject copy. The lower VP copy is equally deleted (indicated by striking through) while the high VP copy survives because it is not c-commanded by any higher copy of VP. The main verb, thus, evades deletion by virtue of having moved to outside of the lower VP copy prior to copy deletion. This gives rise to verb doubling on the surface.

21 The fronted constituent in verb phrase fronting in Polish is actually $v \mathrm{P}$ rather than VP (see Bondaruk 2009,69 , for arguments in favour of this). A more exact structure of verb phrase fronting would therefore be (i) with the fronted $v \mathrm{P}$ containing the subject and the object.

(i) $\quad\left[\mathrm{CP}\left[v \mathrm{P} S\left[v^{\prime} v[\mathrm{vP} \mathrm{V} O]\right]\right]\left[\mathrm{C}^{\prime} \mathrm{C}\left[\mathrm{TP} \mathrm{S}\left[\mathrm{T}^{\prime} \mathrm{T}\left[\operatorname{AspP} \operatorname{Asp}\left[v \mathrm{P} \mathrm{S}\left[v^{\prime} v[\mathrm{vP} \mathrm{V} \mathrm{O}]\right]\right]\right]\right]\right]\right.\right.$

This does not affect the argumentation here, because crucially, the verb head moves as high as Asp. Since Asp is located higher than both VP and $v \mathrm{P}$, the verb leaves the lower copy of the fronted constituent before it is deleted independent of whether it is $\mathrm{VP}$ or $v \mathrm{P}$. The additional copy of the subject inside the fronted $v \mathrm{P}$ will undergo deletion in the same way that the object copy does in a remnant VP movement structure. For reasons of consistency and ease of exposition, I simplify Polish verb phrase fronting to be movement of VP rather than $v \mathrm{P}$. 


\subsection{Lack of verb doubling in German VP-topicalization}

In contrast to Polish above, German does not show verb doubling with VPtopicalization. Instead of a finite copy of the fronted verb, a finite dummy verb tut appears in the V2 position (59). (Recall from Sect. 3.3 that I treat the occurrence of the verb tut 'do' here as unrelated to German tun-periphrase.)

[Das Auto waschen] tut er nie.

the car wash.INF does he never

'Something that he never does is wash the car.'

(German, Diedrichsen 2008, 221)

Since German matrix clauses usually exhibit VP-evacuating verb movement, one would, however, expect it to actually show verb doubling analogous to other languages which independently have VP-topicalization and V-raising. The difference to Polish is that the verb raises all the way to $\mathrm{C}$ in German. Therefore, both the phrasal movement probe and the head movement probe must be located on $\mathrm{C}$. In the current system, this difference is responsible for the lack of verb doubling. The derivation of (59) proceeds as follows.

First, the VP, $v \mathrm{P}$, and TP are generated as usual with the subject moving from its base position in Spec $v$ P to SpecTP (step 1), probing of $\mathrm{T}$ for the subject is ignored here). ${ }^{22}$ Upon merge of $\mathrm{C}$, both of its probes start looking for a goal in the c-command domain of C. According to the Agree algorithm (Himmelreich 2017), the TP node is checked first. As no matching feature is found, next, the subject is probed. Again, no matching feature is encountered. Thus, probing targets the $\mathrm{T}$ head (skipping the $\mathrm{T}^{\prime}$ node as, by assumption, Agree only takes place with $\mathrm{X}^{0}$ and XP categories) and, yet again, no match is found. This continues for $v \mathrm{P}$, the lower copy of the subject, and the $v$ head. Eventually, the VP is encountered. As it bears the [TOP] feature, it matches

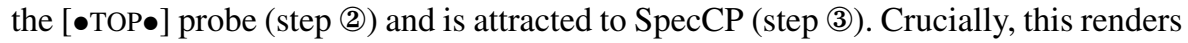
its internals opaque for further subextraction due to the CoMTA (indicated by the rectangle around it, step (4)).

(60) German VP-topicalization: VP-to-SpecCP movement

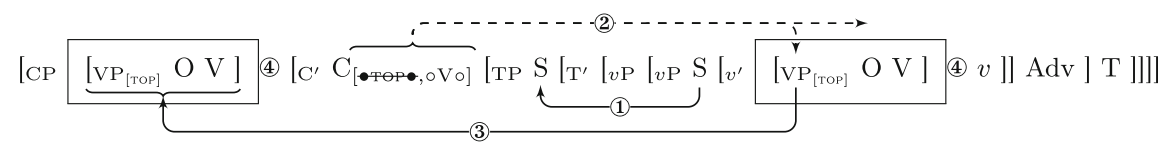

Now, as the head movement probe [oVo] has not yet found a matching goal, it continues probing and finds V (step (5)). However, as V is dominated by VP and VP has been probed and moved already, it fails to trigger V-to-C movement (step (6).

$$
\text { German VP-topicalization: Failed V-raising to } C
$$

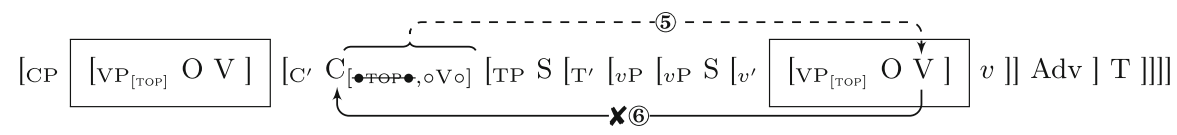

\footnotetext{
22 I explicitly make no claim about the highly controversial issue of subject movement or the existence of $\mathrm{T}$ in German here (for discussion see, e.g., Haider 2010). Subject movement is included in the derivation solely for comparability with the Polish derivation above.
} 
At spell-out, the lower copy of the subject and the lower copy of VP undergo deletion. Equally, the unsatisfied [oVo] feature on $\mathrm{C}$ is discharged as a Last Resort. As a result, the sentence is pronounced with just one lexical verb present in the VP copy in SpecCP (62). A dummy verb tun 'do' is inserted into $\mathrm{C}$ in order to satisfy the requirement that there be a finite verb in the sentence.

(62) German VP-topicalization: Spell-Out

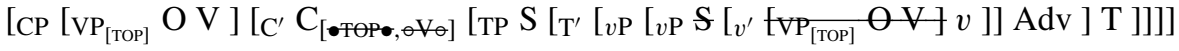
[CP $[\mathrm{VP}$ das Auto waschen $]\left[\mathrm{C}^{\prime}\right.$ tut $\left[\mathrm{TP} \operatorname{er}\left[\mathrm{T}^{\prime}\left[v \mathrm{P}\left[v \mathrm{P}\left[v^{\prime}\right]\right]\right.\right.\right.$ nie $\left.\left.\left.]\right]\right]\right]$

\subsection{Interim summary and discussion}

Wrapping up the present section, I have presented an analysis of verb doubling and the lack thereof as being the consequence of the independent property of whether a language has V-to-T/Asp movement or V-to-C movement. In the former case, the feature triggering V-raising is lower than that triggering topicalization and, therefore, head movement is unaffected by phrasal movement. In the latter case, however, both features are on the same head and probe simultaneously. Since the phrasal probe finds its goal first, VP movement occurs first. Since moved constituents (and their lower copies) are islands for subextraction, V-raising cannot take place anymore, leaving the C-head empty.

Importantly, this analysis presupposes that there is no V-raising to T/Asp independent of V-to-C movement in the languages that lack verb doubling. Otherwise, the trigger for this independent movement, by virtue of being located on $\mathrm{T}$, would be able to attract V out of VP (before VP-to-SpecCP movement later leads to freezing of the latter) (step (1) in (63)). Of the two movement probes on $\mathrm{C}$, the one that triggers $\mathrm{V}$-raising would then encounter its goal, namely the $\mathrm{V}$ inside the complex $\mathrm{V}+\mathrm{T}$ head,

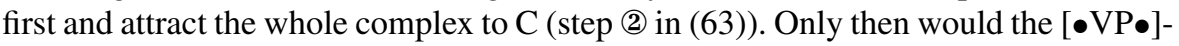
probe on C find its VP-goal and trigger its movement into SpecCP (step (3) in (63)), thereby rendering it opaque for subextraction (step (4) in (63)).

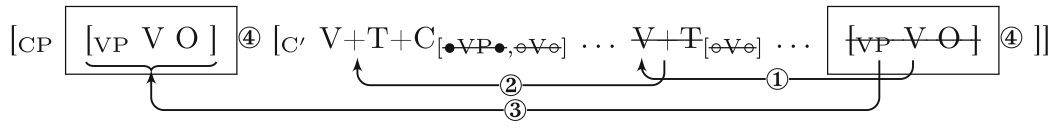

In fact, apart from some exceptions (e.g., Wiklund et al. 2007; see Sect. 6 for a very brief discussion), the Mainland Scandinavian languages, Danish, Norwegian, and Swedish, do not have V-to-T movement independent of V-to-C movement (see, among others, den Besten 1983; Taraldsen 1986; Holmberg 1986; Platzack 1986; Holmberg and Platzack 1995; Vikner 1995; Biberauer and Roberts 2010). This is evidenced by the fact that in non-V2 contexts (64), contrary to V2-contexts (65), the verb stays to the right of VP adverbials such as ofte 'often', which demarcate the left edge of the VP. 
(64) a. Vi ved [at Peter ofte drikker kaffe om morgenen]. we know that Peter often drinks coffee in morning

'We know that Peter often drinks coffee in the morning.'

(Danish, Vikner 1995, 47)

b. Jeg tror [at Hanne ikke liker kaffe].

I believe that Hanne not likes coffee

'I believe that Hanne doesn't like coffee.'

(Norwegian)

c. ... [att jag inte kysste henne].

that I not kissed her

'...that I didn't kiss her.'

(Swedish, Holmberg 1999, 1)

(65) a. Peter drikker ofte kaffe om morgenen.

Peter drinks often coffee in morning.DEF

'Peter often drinks coffee in the morning.' (Danish, Vikner 1995, 47)

b. Hanne liker ikke kaffe.

Hanne likes not koffee

'Hanne doesn't like coffee.'

(Norwegian)

c. Jag kysste henne inte.

I kissed her not

'I didn't kiss her.'

(Swedish, Holmberg 1999, 1)

It has even been argued by some researchers that there is no actual V-to-T movement in V2-clauses either but that V moves directly to C, skipping $\mathrm{T}$ (Biberauer and Roberts 2010; Roberts 2010; Sailor 2018; Gribanova and Mikkelsen 2018; Harizanov and Gribanova 2019). First, V-to-T in V2 is solely enforced by the Head Movement Constraint (Travis 1984), and second, it is not needed to couple the verb and its tense inflection. Since tense inflection shows up on the verb independent of the clause's V2-status (65), there must be some other mechanism, e.g. Agree or Affix Hopping or post-syntactic lowering, that brings V and T together (Holmberg and Platzack 1991). This mechanism would arguably also connect $\mathrm{V}$ and $\mathrm{T}$ in V2 clauses, effectively rendering actual V-to-T movement redundant (Gribanova and Mikkelsen 2018; Harizanov and Gribanova 2019). In addition, this Agree operation between T and V (transferring T's finiteness features to $\mathrm{V}$ ) provides an explanation for the fact that the verb in the fronted VP can be finite in these languages (Lødrup 1990; Teleman et al. 1999; Platzack 2012). Given that Agree (lowering/Affix Hopping) applies before movement of the VP, the verb inside it may come to bear the relevant features to be realized by an inflected form of the verb (for this idea, see also LaCara 2016b). For these reasons, I will adopt the view that there is no actual V-to-T head movement in the Mainland Scandinavian languages for the purposes of this paper.

For German and Dutch, the status of V-to-T movement is somewhat unclear. Due to them being head-final OV languages, movement to $\mathrm{T}$ would be string vacuous. However, Haider (2010, 54-66) argues convincingly that V does not move to $\mathrm{T}$ in V-final clauses in German, but stays in its base position (see also Haider 1993, 62; Vikner 2001; Biberauer and Roberts 2010). It has also often been argued that V-to-T movement is absent in Dutch (Reuland 1990; Koopman 1995; Zwart 1997; Rohrbacher 1999; Biberauer and Roberts 2010). Given this, it is plausible to assume that like in the Scandinavian languages, $\mathrm{T}$ has some other way of coupling with $\mathrm{V}$ that applies 
Table 1 Typology of head movements (incomplete)

\begin{tabular}{llll}
\hline language & V-to-T/Asp & V-to-C & Pattern \\
\hline MSc, Dutch, German & $\boldsymbol{x}$ & $\checkmark$ & Dummy verb \\
Polish, Hebrew, Portuguese & $\checkmark$ & $\boldsymbol{x}$ & Verb doubling \\
English & $\boldsymbol{x}$ & $\boldsymbol{x}$ & $?$ \\
Yiddish & $\checkmark$ & $\checkmark$ & $?$ \\
\hline
\end{tabular}

in both non-V2 and V2 environments. Thus $\mathrm{T}$ in Germanic does not bear a feature triggering head movement of the verb.

The analysis therefore fits well with the data. It also makes the prediction that V2 languages that do in fact show evidence for independent V-to-T movement should exhibit verb doubling. Indeed, Yiddish seems to instantiate this type of language as I will discuss in detail in Sect. 5.2.

\section{Consequences and predictions}

This section adresses some consequences and predictions of the proposed account of (the lack of) verb doubling in VP-topicalization. So far, we have discussed languages that show V-to-T/Asp without V-to-C, namely Hebrew and Polish, and languages that show V-to-C without V-to-T/Asp, namely most Germanic languages. What about languages with other combinations of these two head movements? Do they show verb doubling or dummy verb insertion? The full typology of these two features is presented in Table 1.

\subsection{English VP-topicalization}

As laid out in the previous sections, V-to-T/Asp movement is what gives rise to verb doubling VP-topicalization in languages such as Hebrew and Polish. On the other hand, V-to-C movement (without independent V-to-T) leads to a lack of verb doubling and the presence of a dummy verb in VP-topicalization.

Turning to English VP-topicalization, we find that it does not pattern with Polish and Hebrew, as it does not exhibit verb doubling, but rather patterns with the other Germanic languages in showing dummy verb insertion (66) despite not being V2 (not having $\mathrm{V}$-to-C).

(66) John wanted to read the article and [vp read the article ] he did.

This is completely expected under the present approach. First, English does not show V-to-T movement (Pollock 1989). Hence, there is no attractor outside the VP that could trigger verb raising out of the VP before that VP is deleted as the lower copy in a VP-topicalization movement (67).

$\ldots$ and [vp read the article] $\mathrm{C}$ he $\mathrm{T}$ did [vP read the article]. 
The difference to the other Germanic languages is that it also generally lacks V-to-C movement. However, what derives the lack of verb doubling in those languages is not the presence of $\mathrm{V}$-to-C, but rather its being exceptionally impossible in exactly those cases where a VP is also attracted by $\mathrm{C}$. Thus, while the general properties of Germanic languages - availability of VP-topicalization and VP-evacuating V-raising-incorrectly lead us to expect verb doubling, the general properties of English - availability of VP-topicalization and absence of VP-evacuating V-raisinglead us to correctly expect it to lack verb doubling. What derives the Germanic anomaly in the languages other than English is thus that they become like English in the relevant configurations in not allowing V-to-C movement.

Distilling the proper generalization: Verb doubling requires V-to-T/Asp movement. The lack of verb doubling is not tied to the presence of $\mathrm{V}$-to- $\mathrm{C}$ but more precisely to the absence of V-to-T/Asp movement. ${ }^{23}$

\subsection{Yiddish VP-topicalization}

Yiddish is a Germanic V2 language. In contrast to most other Germanic V2 languages, however, it has been argued to show V-to-T movement independent of V-to-C movement (Vikner 1995, 138-140). The main argument comes from embedded topicalization. Yiddish more or less freely allows embedded V2 clauses. However, there are some environments, such as indirect questions, in which true V2 (i.e., non-subject-

23 An anonymous reviewer made the objection that most English-based creoles and pidgins show verb doubling (i) even though (under most analyses) they lack V-to-T movement. Under the current approach, these would be predicted to lack verb doubling.
a. Nà go à dè go ò. FOC go 1SG.SBJ IPFV go SP
'[Mind you] I'm going.'
b. Is walk (that) Tim walking.
COP walk C T. walk.PROG
'Tim is WALKING (as opposed to running, etc.)'

(Pichi, Yakpo 2009, 297)

(Trinidad Dialectal English, Cozier 2006, 660)

Crucially, though, most creoles and pidgins do not allow focus fronting of more than a bare verb (Bickerton 1993, 193, Cozier 2006, 661). Fronting of other VP-material is ungrammatical (ii).

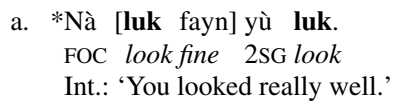

b. *Is [walk to work] that Tim walking (to work).

COP walk to work C T. walk.PROG

Int.: 'Tim is WALKING TO WORK (as opposed to running to the store, etc.)'

(Trinidad Dialectal English, Cozier 2006, 662)

It is argued that this bare V-fronting is in fact not (possibly remnant) VP-movement but rather involves $\bar{A}$-head movement of V, i.e. movement of V into a specifier position (see Koopman 1984; Landau 2006; Vicente 2007, 2009; Harizanov 2019). As argued by Hein (2018) (also see Arregi and Pietraszko 2020a for supporting evidence), this special type of movement always leads to verb doubling because its lowest copy is exempt from copy deletion. Given this, it is not surprising that many creoles and pidgins show verb doubling despite lacking V-to-T movement. 
initial V2) is not available (68a) but subject-initial V2 orders are permitted (68b) and in fact are obligatory $(68 \mathrm{c})$.

a. *Miriam hot gefregt [ ven dos dozike bukh hot Avrom deriber geleyent ].

M. has asked when the that book has Avrom about.it read

b. Miriam hot gefregt [ ven Avrom hot deriber geleyent dos dozike bukh ]. $M \quad$ has asked when A. has about.it read the that book

c. *Miriam hot gefregt [ ven hot Avrom deriber geleyent dos dozike bukh ]. M. has asked when has A. about.it read the that book 'Miriam asked when Avrom has read this book about it.'

(Vikner 1995, 139f.; translation by me)

As Vikner (1995) argues, the different grammaticality status of the V2 orders in (68a) compared to (68b) can be taken to indicate that the finite verb in (68b) has moved to T with the subject ocurring in SpecTP. As (68c) shows, this movement is obligatory. An analogous analysis is not available for (68a) (i.e., finite verb in T, topicalized phrase in SpecTP), because topicalization necessarily has to take place into an $\mathrm{A}^{\prime}$-position, such as SpecCP, and SpecTP is an A-position. The only possible derivation for (68a) would thus be one in which dos dozike bukh has moved into a SpecCP position (in a recursive $\mathrm{CP}$ structure) and the finite verb has risen to $\mathrm{C}$. In other words, (68a) can only be a proper V2-configuration (69a) (in contrast to (69b)) which, for some reason, is not allowed with (this type of) indirect questions.

a. *... ven [CP dos dozike bukh [ $\mathrm{C}^{\prime}$ hot [TP Avrom deriber geleyent ]]].

b. ... ven [TP Avrom [ $\mathrm{T}^{\prime}$ hot [VP deriber geleyent dos dozike bukh ]]].

That there is actual verb movement in subject-initial embedded V2 sentences, rather than the verb staying in its base position with the subject appearing in Spec $v \mathrm{P}$ is evidenced by the behaviour of particle verbs like avekshikn 'to send away'. In (70a), it occurs in its undivided form embedded under an auxiliary. In (70b) it appears in a root $\mathrm{V} 2$ clause, where it has moved to $\mathrm{C}$, stranding its particle in its base position. In (70c), it occurs in an embedded subject-initial V2 clause, where it occurs in second position like the finite verb in (69b); however, this cannot be its base position because it now precedes the stranded particle avek 'away'.

a. Ikh vel avekshikn dos bukh.

I will away.send the book

'I will send away the book.'

b. Max shikt avek dos bukh.

Max sends away the book

'Max sends away the book.'

c. Avrom gloybt az Max shikt avek dos bukh.

Avrom believes that Max sends away the book

'Avrom believes that Max sends away the book.'

(Diesing 1990, 42)

That said, as Yiddish shows independent V-to-T movement, the current approach predicts that VP-topicalization to SpecCP should give rise to verb doubling. This is because the $\mathrm{T}$ head bears a [oVo]-feature and therefore attracts the verb out of the 
Table 2 Typology of head movements

\begin{tabular}{llll}
\hline language & V-to-T/Asp & V-to-C & pattern \\
\hline MSc, Dutch, German & $\mathbf{x}$ & $\checkmark$ & dummy verb \\
Polish, Hebrew, Portuguese & $\checkmark$ & $\mathbf{x}$ & verb doubling \\
English & $\mathbf{x}$ & $\mathbf{x}$ & dummy verb \\
Yiddish & $\checkmark$ & $\checkmark$ & verb doubling \\
\hline
\end{tabular}

VP (71). When the $C$ head merges later on in the derivation, it bears two features, the $[\bullet T O P \bullet]-f e a t u r e$ triggering phrasal movement of the VP to SpecCP, and another $[\circ \mathrm{Vo}]$-feature that ensures that the resulting sentence has V2 order. Crucially, at the point when both of C's probes start searching for a goal, there is one copy of $\mathrm{V}$ that is not dominated by VP, namely the one in T. So whichever probe finds its goal first, there will not be any bleeding effects due to CoMTA, and VP as well as the V+T complex can undergo their respective movements into the $\mathrm{C}$ domain without hindrance, with superfluous copies being deleted at PF (71).

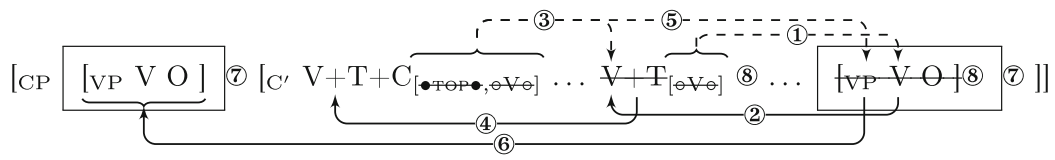

Indeed, as predicted by this analysis, Yiddish exhibits verb doubling in a VPtopicalization configuration, with the finite verb occurring in second position (72).

$$
\begin{aligned}
& \text { [vp Essen fish ] est Maks. } \\
& \text { eat.INF fish eats Max } \\
& \text { 'As for eating fish, Max eats them.' }
\end{aligned}
$$

(Cable 2004, 4)

We can thus complete the typology of V-toT/Asp and V-to-C as in Table 2.

As is clear from the table, it is not the presence of $\mathrm{V}$-to- $\mathrm{C}$ movement that gives rise to the lack of verb doubling, but rather the absence of V-to-T movement.

\subsection{Afrikaans VP-topicalization}

Afrikaans is another Germanic V2 language. Like its sister, Dutch, it shows an asymmetry in the position of the finite verb in root clauses and embedded clauses, with V2 in the former and V-final word order in the latter. It has therefore been analysed as an OV language (Waher 1982; Oosthuizen 1985). Given this, we would take it to show V-to-C movement in matrix clauses and, in the absence of evidence to the contrary, no independent V-to-T movement, parallel to the two other Germanic OV languages German and Dutch.

Like German and Dutch, Afrikaans allows VP-topicalization with stranded auxiliaries (73).

(73) [vP Die boek gelees ] het ek nog nie.

the book read.PTCP have I PRT never

'I have never read the book.'

(Biberauer 2002, 50, note 2) 
Since there is no evidence for V-to-T movement in the language, the current approach predicts it to exhibit no verb doubling in VP-topicalization constructions without auxiliaries or modals. Indeed, this seems to be correct (74a). Instead, a dummy verb appears in second position (74b), as is also the case in German and Dutch, too.

a. *[vp Die boek skryf ] skryf hy (maar hy wil dit nie publiseer nie). the book write.INF writes he but he wants it not publish not 'As for writing the boek, he does that (but he does not want to publish it).'

b. [vP Die boek skryf ] doen hy (maar hy wil dit nie publiseer nie). the book write.INF does he but he wants it not publish not 'As for writing the boek, he does that (but he does not want to publish it).'

(Erin Pretorius, p.c.)

In a corpus-based investigation of the modern spoken language in comparison to the written standard, however, Biberauer (2002) has found that about $40 \%$ of embedded complementizer-introduced declaratives show the verb in second position as in (75).

Ek denk [ dat jy sal die boek baie geniet].

I think that you will the book much enjoy

'I think that you'll enjoy the book very much.'

(Biberauer 2002, 38)

As the preverbal position in these clauses is limited to subjects (Biberauer 2002), similar to what was the case in the Yiddish example in (68), Biberauer (2002) rejects an analysis as genuine V2 clauses (i.e., clauses with the finite verb in C). She instead suggests that the verb appears in T. If this is on the right track, then Afrikaans as an OV language must at least optionally allow independent V-to-T movement. This challenges the generalization that verb doubling VP-topicalization is a direct consequence of the independent availability of V-to-T movement.

Closer inspection, however, reveals that $84 \%$ of the finite verbs that appear in embedded V2 declaratives are functional verbs like modals or auxiliaries (Biberauer 2002, 42), which arguably are base-merged in T. Hence, they do not provide strong evidence for the existence of independent V-to-T movement in Afrikaans. Judgements of native speakers corroborate this. They consistently judged embedded V2 declaratives with a lexical verb in second position to be bad while those with a functional verb in this position were not similarly rejected (Biberauer 2002, 42).

Consequently, the generalization that V-to-T movement is the crucial factor in determining whether verb doubling occurs can be upheld.

\subsection{Non-Germanic dummy verb insertion}

Let us briefly turn to two of the non-Germanic languages that lack verb doubling in VP-fronting configurations, namely Breton and Welsh. It has been pointed out in Sect. 4.1 that both of them can be analysed as having V-to-C movement. In light of the developed analysis, the crucial issue with these languages is whether they also lack independent V-to-T movement.

For both languages, however, the consensus in the literature seems to be that what can be analysed as V-to-C movement is actually more plausibly V-movement to the 
highest inflectional head (see among others Harlow 1981; Rouveret 1990, 1994; Roberts 2000, 2004 for Welsh; Borsley et al. 1996; Jouitteau 2005 for Breton). If this is true, the trigger for V-raising is located on a different, lower head ( $\mathrm{T}$ in standard phrase structure, Fin in cartographic approaches, Rizzi 1997) than that for VP-fronting (which targets SpecCP or, alternatively, SpecTopP). All else being equal, we would therefore expect that both languages show verb doubling rather than dummy verb insertion because the head that attracts the verb is merged before the head that attracts the VP. Alas, Breton (76a) and Welsh (76b) exhibit a finite dummy verb instead of a verb doublet in VP-fronting constructions. ${ }^{24}$

a. [vp Lenn al levr ] a ra Yann.

read the book PRT does Yann

'Read the book, Yann does.'

(Breton, Legendre 2001, 258)

b. [vp Pori'r comin a'r cloddiau ] a wnaeth Ifas am y browse.the common and.the hedges PRT did.3SG Ifas for the lleill.

others

'Ifas BROWSED THE COMMON AND THE HEDGES for the others.'

(Welsh, Tallerman 1996, 100)

For Welsh, this is not a problem. In contrast to the Germanic languages (see Sect. 3.3), there is an independently available analytic verb construction involving a finite occurrence of gwneud 'do' and a lexical verb in the infinitive (77a) which is equivalent in meaning and likelihood of occurrence (at least in colloquiual speech) to the corresponding synthetic form (77b) (Sproat 1985; Borsley et al. 2007).

\section{a. Gwnaeth Siôn weld draig.} do.3SG.PST John see dragon

b. Gwelodd Siôn ddraig. see.3SG.PST John dragon 'John saw a dragon.'

(Welsh, Sproat 1985, 176)

The Welsh VP-fronting in (76b) could then simply be derived from such a periphrastic construction by means of VP-movement stranding the auxiliary gwneud, analogous to other cases of VP-fronting with auxiliary stranding. In order to exclude optional VP-fronting with verb doubling, there must then be some constraint that bans VPfronting in the absence of an auxiliary. Thus, despite having V-to-T movement, Welsh does not show verb doubling because it has an independent dummy verb construction from which VP-fronting is derived. This line of analysis is corroborated by the fact that with stative verbs, where gwneud-periphrasis is ungrammatical for independent reasons (78a), it is not possible to strand a finite form of gwneud (78b). Instead, a different placeholder verb, namely bod 'to be', appears in finite form (78c).

\footnotetext{
24 Note that Breton recently innovated verb doubling in bare verb-fronting contexts with a very narrow (and dialectally variable) set of verbs (Jouitteau 2011). Due to this restriction and the fact that bare verb-fronting shows quite distinct syntactic behaviour from VP-fronting (Borsley et al. 1996; Jouitteau 2011) I will not be concerned with this doubling in this paper.
} 
a. *Mi wnâi ddeall Cymraeg Canol yn berffaith. PRT did know Welsh Middle PRED perfect Intended: 'He knew Middle Welsh perfectly.'

b. *[Deall Cymraeg Canol] a wnâi yn berffaith. know Welsh Middle REL did PRT perfect Intended: 'Know Middle Welsh he did perfectly.'

c. [Deall Cymraeg Canol] yr oedd yn berffaith.

know Welsh Middle C was PRED perfect

'He knew Middle Welsh perfectly.' (Welsh, Rouveret 2012, 918, 919)

In Breton, a similar periphrastic construction is ungrammatical (79).
a. *Anna a ra lenn al levr.
Anna PRT does read the book
b. *Al levr a ra lenn Anna. the book PRT does read Anna

(Breton, Legendre 2001, 258)

However, in contrast to Welsh, Breton is commonly taken to be a V2 language (Schafer 1994, 1995; Borsley and Kathol 2000; Jouitteau 2005). According to Roberts (2004) and Holmberg (2015), the V2 property is made up of two components (80).

Components of V2 (Holmberg 2015, 375, my emphasis)

a. A functional head in the left periphery attracts the finite verb.

b. This functional head wants a constituent moved to its specifier position.

That is, whichever head triggers V-raising also triggers VP-movement in a V2 language. If $\mathrm{V}$ indeed moves to $\mathrm{T}$ in Breton, then as a V2 language, the sole preverbal constituent must be in SpecTP. Such an analysis of V2 has been proposed for other languages as well, among them Yiddish (Diesing 1988, 1990) and Icelandic (Rögnvaldsson and Thráinsson 1990; Iatridou and Kroch 1992, though it is no longer a current analysis of Icelandic V2), which are therefore sometimes referred to as I-V2 languages (Holmberg 2015). Under this analysis, Breton behaves as expected; both probes would be on T, and V-raising would be blocked by prior VP-movement leading to a lack of verb doubling.

It would, of course, be of interest to take a closer look at various other languages, in particular at non-Germanic languages with V2-like properties, for example Kashmiri (Bhatt 1999), Sorbian (Stone 2002), Estonian (Ehala 2006) and Dinka (van Urk 2015). ${ }^{25}$ The predictions for those are clear: They should show verb doubling in case they have independent V-to-T/Asp movement coupled with the absence of an independent dummy verb periphrase. They should, however, lack verb doubling in case they do not have independent V-to-T/Asp movement or do have an independent dummy verb construction at their disposal. For reasons of space, and because they diverge from the main focus of this paper, I will leave these questions open for now.

\footnotetext{
25 Dinka apparently does not allow VP-fronting comparable to Germanic VP-topicalization (Coppe van Urk, p.c.).
} 


\section{Embedded clauses}

Within the Germanic V2 languages, there is some variation as to whether they show V2 order, i.e. V-raising, in root clauses (RCs) only or also in embedded clauses (ECs) with an overt complementizer. Generally, three groups of languages are distinguished. The first one does not allow embedded V2 with an overt complementizer at all. Dutch and German are languages of this type. As is well known, in these languages, overt complementizers force V-final word order and V2 is ungrammatical, as exemplified in (81) for German.

a. Sie bezweifelt, dass er ein Buch liest. she doubts that he a book reads 'She doubts that he is reading a book.'

b. *Sie bezweifelt, dass er liest ein Buch. she doubts that he reads a book

(German)

It is, however, possible for some matrix verbs to optionally embed a complementizerless V2 sentence as shown in (82).
a. Sie glaubt, dass er ein Buch liest. she believes that he a book reads
b. Sie glaubt, er liest ein Buch. she believes he reads a book
'She believes (that) he is reading a book.'

(German)

The second group contains languages that generally allow embedded V2 with an overt complementizer. Yiddish and Icelandic are members of this group. An example of an embedded V2 sentence with a matrix verb that is unable to embed V2 in German (and most other Germanic languages) is given in (83).

$$
\begin{aligned}
& \text { Jonas tsveyfelt az morgen vet Miriam fri oyfshteyn. } \\
& J \text { doubts that tomorrow will M. early get.up } \\
& \text { 'Jonas doubts that Miriam will get up early tomorrow.' }
\end{aligned}
$$

(Yiddish, Vikner 1995, 72)

The third group consists of languages which, in addition to their more common regular embedded V3 order, allow complementizer-introduced V2 complement clauses (in fact, they require the presence of a complementizer in an embedded V2 clause) but only under a certain condition. This condition has been argued by some to be the type of matrix verb; only so-called 'bridge-verbs' allow embedded V2 (see, e.g., de Haan and Weermann 1986; Iatridou and Kroch 1992; Vikner 1995), and by others to be the illocutionary force, such that embedded clauses are more likely to allow V2 the more assertive they are (see, e.g., Hooper and Thompson 1973; Andersson 1975; Green 1976; Wechsler 1991; Holmberg and Platzack 1995; Truckenbrodt 2006; Julien 2007, 2009; Bentzen 2014). Danish, Norwegian, and Swedish belong to this group. As the Norwegian example in (84a) shows, the finite verb in the embedded clause precedes the negation, an indication that V-raising has taken place, and the single constituent preceding the finite verb is a non-subject, an indication that it is a true 
V2 configuration. The same configuration under a different matrix verb, however, is ungrammatical (84b). The more common regular word order in a standard embedded clause is given in $(84 \mathrm{c})$.

(84) a. Han trodde at denne filmen hadde vi ikke sett. he believed that this film.DEF had we not seen 'He believed that this film we hadn't seen.'

b. *Han tvilte på at denne mannen hadde hun ikke møtt. he doubted on that this man.DEF had she not met

(Norwegian, Wiklund et al. 2009, 1919)

c. Han trodde at vi ikke hadde sett denne filmen. he believed that we not had seen this film.DEF 'He believed that we hadn't seen this film.'

(Norwegian)

\subsection{Group 1: no complementizer-introduced embedded V2}

Starting with Group 1, it seems clear from the complementary distribution of complementizers and V2 that the verb in embedded V2 clauses occupies the C-position. Thus, these clauses involve $\mathrm{V}$-to-C movement just like root clauses. In both types of embedded clauses, the verb could therefore not escape the VP prior to a hypothetical VP-topicalization because it does not raise at all in regular ECs (compare English lack of verb doubling) and raises to the head that also attracts the VP in embedded V2 clauses (compare MSc and Dutch/German matrix clause lack of verb doubling). Thus, we would expect both clause-types to not exhibit verb doubling. This prediction holds both for embedded VP-topicalization, where the VP does not leave the EC, i.e. the final landing site is the embedded SpecCP (85a), and for long distance VP-topicalization, where the VP-movement inside the EC takes place as an intermediate step through the embedded SpecCP (85b).

$$
\begin{aligned}
& \text { a. }\left[\mathrm{CP} X P\left[\mathrm{C}^{\prime} \mathrm{V}+\mathrm{C} \ldots[\mathrm{CP} \underbrace{\mathrm{VP}}\left[\mathrm{C}^{\prime} \mathrm{C} \ldots \mathrm{VP}\right]]\right]\right] \\
& \text { b. [CP VP [ } \underbrace{\prime} \mathrm{V}+\mathrm{C} \ldots[\mathrm{CP} \underbrace{\mathrm{VP}}\left[\mathrm{C}^{\prime} \mathrm{C} \ldots \mathrm{VP}\right]]]]
\end{aligned}
$$

In German, embedded VP-topicalization is only available in embedded V2 clauses (86), where it gives rise to dummy verb insertion (86a), as expected.
a. Ich glaube, [CP [vP das Bad putzen ] tust/*putzt du nur I believe the bathroom clean.INF do/clean you only widerwillig ].
reluctant
'I think that clean the bathroom you do only reluctantly.'
b.?*Ich glaube, [CP dass [vP das Bad putzen ] du nur widerwillig tust/putzt ].

(German)

As for long distance VP-topicalization, extraction from embedded V2 is generally possible and results in dummy verb insertion, as predicted (87a). For dass-clauses, there is regional variation with regard to extractability from them. For the speakers 
that allow this, VP-topicalization leads to dummy verb insertion again, as we would expect (87b).
a. [vp Das Bad putzen ], glaube ich, [CP tust/*putzt du nur the bathroom clean.INF believe I do/clean you only widerwillig ]. reluctantly
'Clean the bathroom, I believe you do only reluctantly.'
b. [vP Das Bad putzen ], glaube ich, [CP dass du nur widerwillig tust/*putzt ]. (German)

Thus, for Group 1, the empirical pattern fits the one we expect given the proposed analysis.

\subsection{Groups 2 and 3: complementizer-introduced V2}

Let us first discuss regular non-V2 embedded clauses in Danish, Norwegian, and Swedish (Group 3). As these languages lack independent V-to-T movement in embedded clauses, we expect them to behave like Dutch and German (and English) with regard to VP topicalization. That means that, in a regular non-V2 embedded clause, the verb does not raise out of the VP and therefore undergoes regular copy deletion as part of the lower VP copy in the VP-topicalization chain. Therefore, verb doubling is predicted to be absent. Indeed, this is what we find with long distance topicalization in Swedish (88a) and Norwegian (89a), where a dummy verb occurs. As embedded topicalizations are ungrammatical in a non-V2 embedded sentence in general (Brandtler 2008), the corresponding embedded VP topicalizations are out (where the order of negation before dummy verb indicates that no V2 movement has taken place).

a. [VP Läste boken ] sa John [CP att han gjorde ]. read.PST book.DEF said John that he did

'Read the book, John said that he did.' (Swedish, Platzack 2012, 280)

b. *John sa att [CP [vP läste boken ] (vi) inte gjorde (vi) ].

(Swedish, Samuel Andersson, p.c.)
a. [VP $(\AA)$ lese boken ] trodde hun [CP at vi ikke gjorde ].
to read.INF book believed she that we not did
'Read the book, she believed that we didn't do.'

b. *Hun trodde at [CP [vP (å) lese boken ] (vi) ikke gjorde (vi) ].

(Norwegian)

Turning to embedded V2 clauses, in Groups 2 and 3, compared to Group 1, there is an additional complication introduced by the fact that there is an overt complementizer. A simple $\mathrm{V}$-to-C analysis of V2 is not feasible, because the overt complementizer occupies the $\mathrm{C}$ position. It has therefore been proposed that these clauses contain two CP-layers, an idea referred to as $\mathrm{CP}$-recursion, where the higher $\mathrm{C}_{1}$ hosts the complementizer and the lower $\mathrm{C}_{2}$ hosts the finite verb and the preverbal constituent (90a) (see Iatridou and Kroch 1992; Holmberg 1986; Platzack 1986; de Haan and Weermann 1986; Holmberg and Platzack 1995; Vikner 1995; Heycock 2006; Wik- 
lund et al. 2007, 2009; Brandtler 2008). Another analysis takes embedded V2 (and also matrix V2) clauses to involve V-to-T movement with the preverbal constituent appearing in SpecTP and the complementizer, as usual, in C (90b) (as suggested for Yiddish by Diesing 1988, 1990; Santorini 1989; Heycock and Santorini 1992; Iatridou and Kroch 1992; and for Icelandic by Thráinsson 1986; Rögnvaldsson and Thráinsson 1990; Iatridou and Kroch 1992, though see Wiklund et al. 2007, 2009 for arguments that Icelandic embedded V2 involves V-to-C movement).

$$
\begin{array}{llr}
\text { a. } & \ldots\left[\mathrm { C } _ { 1 } \mathrm { P } \mathrm { C } _ { 1 } \left[\mathrm{C}_{2} \mathrm{P} X \mathrm{XP} V+\mathrm{C}_{2}[\mathrm{TP}\right.\right. & \mathrm{T} \ldots]]] \\
\text { b. } & \ldots[\mathrm{CP} \mathrm{C} & [\mathrm{TP} X \mathrm{XP}+\mathrm{T} \ldots]]
\end{array}
$$

Depending on which analysis is chosen, the current proposal makes different predictions for verb doubling in embedded V2 clauses. As Icelandic does not show VP-topicalization (Thráinsson 2007, 349), I will ignore it in what follows. Let us first consider Yiddish (Group 2), where V2 order is not restricted to root clauses or $\mathrm{CP}$-complements of a narrow set of verbs, but is more or less freely available in most embedded clauses (Diesing 1990, 42; Jacobs et al. 1994, 409). In a CP-recursion analysis, $\mathrm{C}_{2}$ attracts both the VP and the verb. However, as Yiddish has independent V-to-T movement (see Sect. 5.2), the verb can leave the VP before it becomes opaque for extraction when the $\mathrm{C}$ head has triggered VP-topicalization. Thus, we would expect verb doubling to occur in VP-topicalizations from embedded clauses. As (non-verbal) topicalization is possible both in embedded (91a) as well as long distance contexts (91b), I would expect the corresponding VP-topicalizations in (92) to also be possible, crucially exhibiting verb doubling. ${ }^{26}$

(91) a. Jonas bedoyert az dos bukh hob ikh geleyent.

Jonas regrets that this book have I read

'Jonas regrets that I have read this book.'

b. Vos hot er nit gevolt az di kinder zoln leyenen?

what has he not wanted that the children shall read

'What did he not want that the children should read?'

(Yiddish, Vikner 1995, 72, 115)

(92) Predicted sentences under the CP-recursion analysis of embedded V2

a. Jonas bedoyert az [vp leyenen dos bukh ] leyn ikh.

Jonas regrets that read this book read I

'Jonas regrets that read this book I do.'

b. [vP Leyenen dos bukh ] hot er nit gegloybt az di kinder leyenen.

read this book has he not believed that the children read

'Read this book has he not believed that the children do.'

(Yiddish, hypothetical)

\footnotetext{
26 Embedded topicalization and long distance topicalization differ with regard to the exact position to which the topicalized phrase moves within the embedded clause. In the former context, the topicalized phrase lands in $\mathrm{SpecC}_{2} \mathrm{P}$, its final landing site, while in the latter context, it moves to $\mathrm{SpecC}_{1} \mathrm{P}$, the edge of the embedded clause, from where it undergoes further movement to its final landing site outside the embedded clause.
} 
Table 3 Predictions for VP-topicalization in/from embedded V2 clauses in Yiddish

\begin{tabular}{lll}
\hline & embedded topicalization & long distance topicalization \\
\hline CP-recursion & verb doubling & verb doubling \\
V-to-T & no verb doubling & verb doubling \\
\hline
\end{tabular}

Under a V-to-T analysis of embedded V2, the T head attracts both VP and V. However, in this case there is no independent prior head movement of the verb to a position outside the VP. Thus, when T probes for VP and V, it should find VP first and trigger its movement to SpecTP, which in turn renders the low VP copy opaque for extraction of V. Therefore, for embedded VP-topicalizations, we would expect no verb doubling (93a). In contrast, if the VP moves to outside the embedded clause, it has to undergo intermediate movement to SpecCP, rather than SpecTP. In this case, the VP-attracting head (a $\mathrm{C}$ with an edge feature) and the $\mathrm{V}$-attracting one ( $\mathrm{T}$ ) would be distinct, with the former being structurally higher than the latter. This configuration should give rise to verb doubling as in $(93 \mathrm{~b}){ }^{27}$

\section{Predicted sentences under the V-to-T analysis of embedded V2}

a. Jonas bedoyert az [VP leyenen dos bukh ] tu ikh.

Jonas regrets that read this book do I

'Jonas regrets that read this book I do.'

b. [vP Leyenen dos bukh ] hot er nit gegloybt az di kinder leyenen.

read this book has he not believed that the children read

'Reading this book is not what he believed that the children do.'

(Yiddish, hypothetical)

The predictions are summarized in Table 3.

In a cursory survey, ${ }^{28}$ judgements on four sentences were collected, namely (93a) (embedded topicalization) and (93b) (long-distance topicalization), each in two variants, one with a verb doublet (leyn/leyenen), the other with a dummy verb (tu/ton). The results from 4 Yiddish speakers are given in Table 4 , where ' $\mathcal{J}$ ' indicates grammaticality, '*' indicates ungrammaticality, and '?' indicates 'strange but not all bad'.

There seems to be a preference for dummy verbs in both embedded and long-distance VP-topicalization. This result favours neither of the two theoretical approaches presented above. However, this might be due to the fact that all four speakers did not accept verb doubling under VP-topicalization, even in a matrix clause (as

\footnotetext{
27 Proponents of the V-to-T analysis of embedded V2 generally assume that it also holds for matrix V2 clauses. If this were true, the current analysis would predict that Yiddish should lack verb doubling in matrix clauses, contrary to fact, as the T head would attract both the verb and the VP. While there is no logical necessity between a V-to-T analysis of V2 in embedded clauses and in matrix clauses, the presence of verb doubling in matrix clauses might render the V-to-T analysis of embedded V2 clauses less plausible.

28 This survey was kindly set up and conducted for me by Chaya R. Nove at the Graduate Center at City University of New York.
} 
Table 4 Judgements of Yiddish speakers on VP-topicalization

\begin{tabular}{lllllllll}
\hline Speakers & & 1 & 2 & 3 & 4 & $\checkmark$ & $?$ & $*$ \\
\hline embedded & doublet & $*$ & $?$ & $*$ & $*$ & 0 & 1 & 3 \\
& dummy & $?$ & $?$ & $*$ & $\checkmark$ & 1 & 2 & 1 \\
long-distance & doublet & $*$ & $?$ & $*$ & $*$ & 0 & 1 & 3 \\
& dummy & $?$ & $*$ & $\checkmark$ & $\checkmark$ & 2 & 1 & 1
\end{tabular}

Table 5 Predictions for VP-topicalization in/from embedded V2 clauses in MSc

\begin{tabular}{lll}
\hline & embedded topicalization & long distance topicalization \\
\hline CP-recursion & no verb doubling & verb doubling \\
V-to-T & no verb doubling & verb doubling
\end{tabular}

evidenced by their judgements on (72)). ${ }^{29}$ Further and more careful investigation of the issue will be left to future research.

For Danish, Norwegian, and Swedish, the difference compared to Yiddish, besides the limited availability of embedded V2, is that there is no evidence for independent V-to-T movement (see Sect. 4.6). The CP-recursion analysis therefore makes the prediction that embedded VP-topicalization should result in a lack of verb doubling. Assuming that extraction from the embedded clause proceeds via $\operatorname{SpecC}_{1} \mathrm{P}$, long distance VP-topicalization, in contrast, should give rise to verb doubling. This is because the head that attracts $\mathrm{V}\left(\mathrm{C}_{2}\right)$ is different from and lower in the structure than the head that attracts the VP $\left(\mathrm{C}_{1}\right)$. Under a V-to-T analysis (for Danish subject-initial matrix clauses, see Mikkelsen 2015), the predictions remain the same. Embedded VP-topicalization should result in a lack of verb doubling, as T attracts both V and VP, whereas long distance VP-topicalization should give rise to verb doubling, as $\mathrm{T}$ attracts $\mathrm{V}$ but the higher $\mathrm{C}$ attracts $\mathrm{VP}$ via an edge feature. The predictions are summarized in Table 5.

All else being equal, the two analyses thus generate the same predictions for Danish, Norwegian, and Swedish embedded V2 clauses. Embedded VP-topicalizations indeed lack verb doubling, as shown in (94a,b) for Swedish and Norwegian.

a. John sa [CP att [vp läste boken ] gjorde vi inte ]. John said that read book did we not 'John said that read the book we didn't do.'

(Swedish, Samuel Andersson, p.c.)

b. Hun trodde [CP at [VP (å) lese boken ] gjorde vi ikke ]. she believed that to read.INF book.DEF did we not 'She believed that read the book we didn't do.'

(Norwegian)

\footnotetext{
29 While verb doubling under bare V-topicalization is relatively frequent and well-accepted by speakers this is not true for VP-topicalization, which is rarely attested and tends to be judged less acceptable. It is thus not surprising that some speakers of Yiddish reject verb doubling under VP-topicalization completely.
} 
The predictions for long distance VP topicalization are not as easily testable, because topicalization (of arguments and adjuncts) from embedded V2 clauses is ungrammatical in the three languages (Holmberg 1986, 109-115; Holmberg 2015, 360; Vikner 1995, 108-116). There is but one exception to this restriction: argument extraction from a subject-initial embedded V2 clause is claimed to be possible in (some varieties of) Norwegian (Hrafnbjargarson et al. 2010, 304). Whether this also holds for VP-topicalization is unclear at the moment. ${ }^{30}$

To summarize, the predictions that the current approach makes for verb doubling in embedded clauses across many Germanic languages are for the most part borne out. There are two cases for which reliable language data are missing: (i) embedded and long distance VP-topicalization in Yiddish, and (ii) long distance VP-topicalization in one variety of Norwegian.

Acknowledgements For discussions and helpful comments during various stages of this paper that helped to improve it to a significant degree, I would like to express gratitude to Fabian Heck, Andrew Murphy, the audience at CGSW 32 in Trondheim, and three anonymous reviewers at JCGL. Thanks also go to Siri Gjersøe for providing Norwegian data judgements, Joanna Zaleska for her judgements on Polish sentences, Erin Pretorius for judgements on Afrikaans, and Samuel Andersson for judgements on Swedish. Any errors are, of course, mine.

Funding Open Access funding enabled and organized by Projekt DEAL.

Open Access This article is licensed under a Creative Commons Attribution 4.0 International License, which permits use, sharing, adaptation, distribution and reproduction in any medium or format, as long as you give appropriate credit to the original author(s) and the source, provide a link to the Creative Commons licence, and indicate if changes were made. The images or other third party material in this article are included in the article's Creative Commons licence, unless indicated otherwise in a credit line to the material. If material is not included in the article's Creative Commons licence and your intended use is not permitted by statutory regulation or exceeds the permitted use, you will need to obtain permission directly from the copyright holder. To view a copy of this licence, visit http://creativecommons.org/licenses/by/4.0/.

\section{References}

Abels, Klaus. 2001. The predicate cleft construction in Russian. In Annual Workshop on Formal Approaches to Slavic Linguistics: The Bloomington Meeting, ed. S. Frank, T.Holloway King, and M. Yadroff, 1-18. Michigan: Michigan Slavic Publications.

Aboh, Enoch Oladé. 1998. Focus constructions and the focus criterion in Gungbe. Linguistique Africaine 20: 5-50.

Aboh, Enoch Oladé. 2006. When verbal predicates go fronting. In Papers on information structure in African languages, ed. I. Fiedler and A. Schwarz. ZAS Papers in Linguistics 46, 21-48. Berlin: ZAS.

Aboh, Enoch Oladé, and Marina Dyakonova. 2009. Predicate doubling and parallel chains. Lingua 119: 1035-1065.

Abraham, Werner, and Annette Fischer. 1998. Das grammatische Optimalisierungsszenario von tun als Hilfsverb. In Deutsche Grammatik - Thema in Variationen. Festschrift für Hans-Werner Eroms zum 60. Geburtstag, ed. Karin Donhauser, and Ludwig M. Eichinger, 35-47. Heidelberg: Winter.

Aelbrecht, Lobke. 2010. The syntactic licensing of ellipsis. Amsterdam: John Benjamins.

Andersson, Lars-Gunnar. 1975. Form and function of subordinate clauses. PhD dissertation, Göteborg University, Göteborg.

30 Unfortunately, my native speaker consultant, Siri M. Gjersøe, does not allow any exceptions to the ban on long-distance topicalization from embedded V2 clauses at all and I was unable to find speakers that do allow it. 
Arregi, Karlos, and Asia Pietraszko. 2020a. Unifying long head movement with phrasal movement: A new argument from spellout. Talk given at WCCFL 38, UBC Vancouver, 7th of March.

Arregi, Karlos, and Asia Pietraszko. 2020b. The ups and downs of head displacement. Linguistic Inquiry. https://doi.org/10.1162/ling_a_00377.

Assmann, Anke, Doreen Georgi, Fabian Heck, Gereon Müller, and Philipp Weisser. 2015. Ergatives move too early: An instance of opacity in syntax. Syntax 18 (4): 343-387.

Baltin, Mark. 2002. Movement to the higher V is remnant movement. Linguistic Inquiry 32: 653-659.

Baltin, Mark. 2006. The nonunity of VP-preposing. Language 82 (4): 734-766.

Barnickel, Katja. 2017. Deriving asymmetric coordination in German: A non-monotonic approach. PhD dissertation, Universität Leipzig, Leipzig.

Bastos-Gee, Ana Claudia. 2009. Topicalization of verbal projections in Brazilian Portuguese. In Minimalist Essays on Brazilian Portuguese Syntax, ed. Jairo Nunes, 132-155. Amsterdam: John Benjamins.

Bayer, Josef. 2008. What is verb second? Ms.: Universität Konstanz.

Bayer, Josef, and Constantin Freitag. to appear. How much verb moves to second position? In Verb second: Grammar internal and grammar external interfaces, ed. Horst Lohnstein and Antonios Tsiknakis. Berlin: De Gruyter.

Bentzen, Kristine. 2014. Embedded verb second (V2). Nordic Atlas of Language Structures (NALS) Journal 1: 211-224.

Bentzen, Kristine, Jason Merchant, and Peter Svenonius. 2013. Deep properties of surface pronouns: Pronominal predicate anaphors in Norwegian and German. Journal of Comparative Germanic Linguistics 16: 97-125.

Bernabé, Jean. 1983. Fondal-natal, grammaire basilectale approchée des créoles Guadeloupéen et Martiniquais. Paris: L'Harmattan.

Bhatt, Rakesh M. 1999. Verb movement and the syntax of Kashmiri. Dordrecht: Kluwer.

Biberauer, Theresa. 2002. Verb second in Afrikaans: Is this a unitary phenomenon? Stellenbosch Papers in Linguistics 34: 19-69.

Biberauer, Theresa, and Ian Roberts. 2010. Subjects, tense and verb-movement. In Parametric variation: Null subjects in minimalist theory, ed. Theresa Biberauer, Anders Holmberg, Ian Roberts, and Michelle Sheehan, 263-302. Cambridge: Cambridge University Press.

Bickerton, Derek. 1993. Subject focus and pronouns. In Focus and grammatical relations in creole languages, ed. Francis Byrne and Donald Winford, 189-212. Amsterdam: John Benjamins.

Bjorkman, Bronwyn. 2011. BE-ing default: The morphosyntax of auxiliaries. PhD dissertation, MIT, Cambridge, MA.

Blom, Elma. 2003. From root infinitive to finite sentences: The acquisition of verbal inflections and auxiliaries. PhD dissertation, Utrecht University, Utrecht.

Bobaljik, Jonathan. 1995. Morphosyntax: The syntax of verbal inflection. PhD dissertation, MIT, Cambridge, MA.

Boeckx, Cedric, and Sandra Stjepanović. 2001. Head-ing toward PF. Linguistic Inquiry 32 (2): 345-355.

Bohnacker, Ute. 1999. Icelandic plus English: Language differentiation and functional categories in a successively bilingual child. PhD dissertation, University of Durham, Durham.

Bondaruk, Anna. 2009. Constraints on predicate clefting in Polish. In Studies in formal Slavic phonology, morphology, syntax, semantics, and information structure: Proceedings of FDSL 7, Leipzig 2007, ed. Gerhild Zybatow, Uwe Junghanns, Denisa Lenertová, and Petr Biskup, 65-79. Frankfurt a. M.: Peter Lang.

Bondaruk, Anna. 2012. Copy deletion in Polish predicate clefting. In Sound, structure and sense: Studies in memory of Edmund Gussmann, ed. Eugeniusz Cyran, Henryk Kardela, and Bogdan Szymanek, 55-70. Lublin: Katolicki Uniwersytet Lubelski.

Borsley, Robert D., and Andreas Kathol. 2000. Breton as a V2 language. Linguistics 38: 665-710.

Borsley, Robert D., Maria-Luisa Rivero, and Janig Stevens. 1996. Long head movement in Breton. In The syntax of Celtic languages: A comparative perspective, ed. Robert D. Borsley and Ian Roberts, 53-74. Cambridge: Cambridge University Press.

Borsley, Robert D., Maggie Tallerman, and David Willis. 2007. The syntax of Welsh. Cambridge: Cambridge University Press.

Bošković, Željko. 2014. Now I'm a phase, now I'm not a phase: On the variability of phases with extraction and ellipsis. Linguistic Inquiry 45: 27-89.

Brandtler, Johan. 2008. The structure of Swedish subordinate clauses. Working Papers on Scandinavian Syntax 81: 79-97. 
Brody, Michael. 1995. Lexico-Logical Form: A radically minimalist theory. Cambridge, MA: MIT Press.

Broekhuis, Hans, and Norbert Corver. 2015. Syntax of Dutch: Verbs and verb phrases, vol. 2. Amsterdam: Amsterdam University Press.

Cable, Seth. 2004. Predicate clefts and base-generation: Evidence from Yiddish and Brazilian Portuguese. Cambridge, MA: Ms., MIT.

Childs, George Tucker. 2011. A Grammar of Mani. Vol. 54 of Mouton grammar library. Berlin/Boston: De Gruyter Mouton.

Chomsky, Noam. 1995. The Minimalist Program. Cambridge, Mass.: MIT Press.

Chomsky, Noam. 2000. Minimalist inquiries: The framework. In Step by step: Essays on minimalist syntax in honor of Howard Lasnik, ed. Roger Martin, David Michaels, and Juan Uriagereka, 89-155. Cambridge, MA: MIT Press.

Chomsky, Noam. 2001. Derivation by Phase. In Ken Hale. A life in Language, ed. Michael Kenstowicz, 1-52. Cambridge, MA: MIT Press.

Chomsky, Noam. 2008. On phases. In Foundational issues in linguistic theory: Essays in honor of Jean-Roger Vergnaud, ed. Robert Freidin, Carlos P. Otero, and Maria Luisa Zubizarreta, 291-321. Cambridge, MA: MIT.

Clahsen, Harald. 1990/1991. Constraint on parameter setting: A grammatical analysis of some acquisition stages in German child language. Language Acquisition 1 (4): 361-391.

Corver, Norbert. 2006. Freezing effects. In The Blackwell companion to syntax II, ed. Martin Everaert and Henk van Riemsdijk, 383-406. Oxford: Blackwell.

Cozier, Franz K. 2006. The co-occurrence of predicate clefting and wh-questions in Trinidad Dialectal English. Natural Language and Linguistic Theory 24 (3): 655-688.

Davis, Lori J., and Ellen F. Prince. 1986. Yiddish verb-topicalization and the notion of 'lexical integrity'. In Proceedings of the 22nd annual meeting of the Chicago Linguistics Society, ed. Anna M. Farley, Peter T. Farley, and Karl-Eric. McCullough, 90-97. Chicago, IL: University of Chicago, Chicago Linguistic Society.

de Haan, Germen, and Fred Weermann. 1986. Finiteness and verb fronting in Frisian. In Verb second phenomena in Germanic languages, ed. Hubert Haider and Martin Prinzhorn, 77-110. Dordrecht: Foris.

Dekydspotter, Laurent. 1992. The syntax of predicate clefts. In Proceedings of NELS 22, ed. Kimberly Broderick, 119-133. Amherst, MA: GLSA.

den Besten, Hans. 1983. On the interaction of root transformations and lexical deletive rules. In On the formal syntax of Westgermania, ed. Werner Abraham, 47-131. Amsterdam: John Benjamins.

den Dikken, Marcel. 2007. Phase extension. contours of a theory of the role of head movement in phrasal extraction. Theoretical Linguistics 33: 1-41.

Diedrichsen, Elke. 2008. Where is the precore slot? Mapping the layered structure of the clause and German sentence topology. In Investigations of the syntax-semantics-pragmatics interface, Vol. 105 of Studies in Language Companion Series, ed. Robert D. Van Valin Jr. Amsterdam/Philadelphia: John Benjamins.

Diesing, Molly. 1988. Word order and the subject position in Yiddish. In Proceedings of NELS 18, ed. James Blevins and Julie Carter, 124-140. Amherst, MA: GLSA.

Diesing, Molly. 1990. Verb movement and the subject position in Yiddish. Natural Language and Linguistic Theory 8 (1): 41-79.

Doron, Edit. 1999. V-movement and VP-ellipsis. In Fragments: Studies in ellipsis and gapping, ed. Shalom Lappin and Elabbas Benmamoun, 124-140. New York: Oxford University Press.

Duguine, Maia, and Aritz Irurtzun. 2014. From obligatory wh-movement to optional wh-in-situ in Labourdin Basque. Language 90 (1): 1-30.

Ehala, Martin. 2006. The word order of Estonian. Journal of Universal Language 7: 49-89.

Elordieta, Arantzazu. 2001. Verb movement and constituent permutation in Basque. Utrecht: LOT Publications.

Embick, David, and Rolf Noyer. 2001. Movement operations after syntax. Linguistic Inquiry 32 (4): 555595.

Freitag, Constantin. 2019. Verb-second in grammar, processing, and acquisition: What you see is not what you get. $\mathrm{PhD}$ dissertation, Universität Konstanz, Konstanz.

Gallego, Ángel. 2010. Phase theory. Vol. 152 of Linguistik aktuell/linguistics today. Amsterdam/Philadelphia: John Benjamins.

Georgi, Doreen. 2014. Opaque interaction of Merge and Agree: On the nature and order of elementary operations. PhD dissertation, Universität Leipzig. 
Goldberg, Lotus M. 2005. Verb-stranding VP ellipsis: A cross-linguistic study. PhD dissertation, McGill University, Montreal.

Green, Georgia. 1976. Main clause phenomena in subordinate clauses. Language 52: 382-397.

Gribanova, Vera. 2013. Verb-stranding verb phrase ellipsis and the structure of the Russian verbal complex. Natural Language and Linguistic Theory 31 (1): 91-136.

Gribanova, Vera. 2017. Head movement and ellipsis in the expression of Russian polarity focus. Natural Language and Linguistic Theory 35: 1079-1121.

Gribanova, Vera, and Line Mikkelsen. 2018. On the interaction of head movement and ellipsis in Danish. In A reasonable way to proceed: Essays in honor of Jim McCloskey, ed. Jason Merchant, Line Mikkelsen, Deniz Rudin, and Kelsey Sasaki, 105-124. Santa Cruz, CA: eScholarship Publishing.

Groat, Erich, and John O'Neill. 1996. Spell-Out at the interface: Achieving a unified syntactic computational system in the minimalist framework. In Minimal ideas: Syntactic studies in the minimalist framework, ed. Werner Abraham, SamuelD. Epstein, HöskuldurThráinsson, and Jan-Wouter. Zwart, 113-139. Amsterdam: John Benjamins.

Haider, Hubert. 1993. Deutsche Syntax generativ. Tübingen: Narr.

Haider, Hubert. 2010. The syntax of German. Cambridge: Cambridge University Press.

Hale, Ken, and Samuel Keyser. 2002. Prolegomenon to a Theory of Argument Structure. Cambridge, MA: MIT Press.

Halpert, Claire. 2012. Argument licensing and agreement in Zulu. PhD dissertation, MIT, Cambridge, MA. Harbour, Daniel. 2008. Klivaj predika, or predicate clefts in Haitian. Lingua 118: 853-871.

Harizanov, Boris. 2019. Head movement to specifier positions. Glossa 4 (1): 140-136.

Harizanov, Boris, and Vera Gribanova. 2019. Whither head movement? Natural Language and Linguistic Theory 37 (2): 461-522.

Harley, Heidi. 2004. Merge, conflation, and head movement The First Sister Principle revisited. In Proceedings of NELS 34, ed. Keir Moulton and Matthew Wolf, 239-254. Amherst: University of Massachusetts, GLSA.

Harley, Heidi. 2013. Getting morphemes in order: Merger, affixation, and head-movement. In Diagnosing syntax, ed. Lisa Lai-Shen. Cheng and Norbert Corver, 44-74. Oxford: Oxford University Press.

Harlow, Stephen. 1981. Government and relativisation in Celtic. In Binding and filtering, ed. Frank Heny. Cambridge: MIT Press.

Hein, Johannes. 2018. Verbal fronting: Typology and theory. PhD dissertation, Universität Leipzig, Leipzig.

Heycock, Caroline. 2006. Embedded root phenomena. In The Blackwell companion to syntax II, ed. Martin Everaert and Henk van Riemsdijk, 174-209. Oxford: Blackwell.

Heycock, Caroline, and Beatrice Santorini. 1992. Head movement and the licensing of non-thematic positions. In Proceedings of the 11th West Coast Conference on Formal Linguistics, ed. Jonathan Mead, 262-276. Chicago: CSLI Publications.

Himmelreich, Anke. 2017. Case matching effects in free relatives and parasitic gaps: A study on the properties of agree. PhD dissertation, Universität Leipzig, Leipzig.

Hiraiwa, Ken. 2005a. Dimensions of symmetry in syntax: Agreement and clausal architecture. PhD dissertation, MIT, Cambridge, MA.

Hiraiwa, Ken. 2005b. Predicate clefts in Bùlì: The CP/DP symmetry. Linguistic Analysis 32: 544-583.

Hiraiwa, Ken, and Adams Bodomo. 2008. Object-sharing as symmetric sharing: predicate clefting and serial verbs in Dàgáárè. Natural Language and Linguistic Theory 26: 795-832.

Höhle, Tilman. 1983. Subjektlücken in Koordinationen. Ms.: Universität Köln.

Höhle, Tilman. 1990. Assumptions about asymmetric coordination. In Grammar in progress: Glow essays for Henk van Riemsdijk, ed. Juan Mascaro and Marina Nespor, 221-235. Dordrecht: Foris.

Höhle, Tilman. 1991. On reconstruction and coordination. In Representation and derivation in the theory of grammar, ed. Hubert Haider and Klaus Netter, 139-197. Dordrecht: Kluwer.

Holmberg, Anders. 1986. Word order and syntactic features in the Scandinavian languages and English. PhD dissertation, University of Stockholm, Stockholm.

Holmberg, Anders. 1999. Remarks on Holmberg's Generalization. Studia Linguistica 53: 1-39.

Holmberg, Anders. 2015. Verb second. In Syntax-Theory and analysis: An international handbook, vol. 1, ed. Tibor Kiss and Artemis Alexiadou, 342-383. Berlin: de Gruyter Mouton.

Holmberg, Anders, and Christer Platzack. 1991. On the role of inflection in Scandinavian syntax. In Issues in Germanic Syntax, ed. Werner Abraham, Wim Kosmeijer, and Eric Reuland, 93-118. Berlin: Mouton de Gruyter. 
Holmberg, Anders, and Christer Platzack. 1995. The role of inflection in Scandinavian syntax. Oxford: Oxford University Press.

Hooper, Joan, and Sandra Thompson. 1973. On the applicability of root transformations. Linguistic Inquiry 4: 456-497.

Houser, Michael J., Line Mikkelsen, and Maziar Toosarvandani. 2011. A defective auxiliary in Danish. Journal of Comparative Germanic Linguistics 23 (3): 245-298.

Hrafnbjargarson, Gunnar Hrafn, Kristine Bentzen, and Ana-Lena Wiklund. 2010. Observations on extraction from V2 clauses in Scandinavian. Nordic Journal of Linguistics 33 (3): 299-309.

Iatridou, Sabine, and Anthony Kroch. 1992. The licensing of CP-recursion and its relevance to the Germanic verb-second phenomenon. Working Papers in Scandinavian Syntax 50: 1-24.

Iatridou, Sabine, and Hedde Zeijlstra. 2010. On the scopal interaction of negation and deontic modals. In Logic, language and meaning: 17th Amsterdam Colloquium, Amsterdam, The Netherlands, December 16-18, 2009, Revised selected papers, ed. Maria Aloni, Harald Bastiaanse, Tikitu de Jager, and Katrin Schulz, 315-324. Berlin, Heidelberg: Springer.

Irurtzun, Aritz. 2007. The grammar of focus at the interfaces. PhD dissertation, University of the Basque Country (UPV/EHU), Vitoria-Gasteiz.

Jacobs, Neil G., Ellen F. Prince, and Johan van der Auwera. 1994. Yiddish. In The Germanic languages, ed. Ekkehard König and Johan van der Auwera, 388-419. New York: Routledge.

Jónsson, Jóhannes Gísli. 2008. Preposition reduplication in Icelandic. In Microvariation in syntactic doubling. Vol. 36 of Syntax and Semantics, ed. Sjef Barbiers, Olaf Koeneman, Marika Lekakou, and Margreet van der Ham, 403-417. Emerald Group: Bingley.

Jouitteau, Mélanie. 2005. La syntaxe comparée du Breton. PhD dissertation, Université de Nantes, Nantes.

Jouitteau, Mélanie. 2011. Post-syntactic excorporation in realizational morphology, evidence from Breton. In Formal approaches to Celtic linguistics, ed. Andrew Carnie, 115-142. Newcastle upon Tyne: Cambridge Scholars Publishing.

Julien, Marit. 2007. Embedded V2 in Norwegian and Swedish. Working Papers in Scandinavian Syntax 80: 103-161.

Julien, Marit. 2009. The force of the argument. Working Papers in Scandinavian Syntax 84: 225-232.

Källgren, Gunnel, and Ellen F. Prince. 1989. Swedish VP-topicalization and Yiddish verb-topicalization. Nordic Journal of Linguistics 12: 47-58.

Kandybowicz, Jason. 2007. Fusion and PF architecture. In University of Pennsylvania Working Papers in Linguistics 13.1: Proceedings of the 30th Annual Penn Linguistics Colloquium, ed. Tatjana Scheffler, Joshua Tauberer, Aviad Eilam, and Laia Mayol, 85-98. Philadelphia, PA: University of Pennsylvania.

Kandybowicz, Jason. 2008. The Grammar of Repetition. Nupe grammar at the syntax-phonology interface. Vol. 136 of Linguistik Aktuell - Linguistics Today. Amsterdam/Philadelphia: John Benjamins.

Kandybowicz, Jason, and Harold Torrence. 2016. Predicate focus in Krachi: 2 probes, 1 goal, 3 PFs. In Proceedings of the 33rd West Coast Conference on Formal Linguistics, ed. Kyeong min Kim, Pocholo Umbal, Trevor Block, Queenie Chan, Tanie Cheng, Kelli Finney, Mara Katz, Sophie Nickel-Thompson, and Lisa Shorten, 227-236. Somerville, MA: Cascadilla Proceedings Project.

Kayne, Richard. 1994. The antisymmetry of syntax. Cambridge, MA: MIT Press.

Keine, Stefan, and Rajesh Bhatt. 2016. Interpreting verb clusters. Natural Language and Linguistic Theory 34 (4): 1445-1492.

Kitahara, Hisatsugu. 1997. Elementary operations and optimal derivations. Cambridge, MA: MIT Press.

Koopman, Hilda. 1984. The syntax of verbs: From verb movement rules in the Kru languages to Universal Grammar. Dordrecht: Foris.

Koopman, Hilda. 1995. On verbs that fail to undergo v-second. Linguistic Inquiry 26 (1): 137-163.

Koopman, Hilda. 2000. Unifying predicate cleft constructions. In The syntax of specifiers and heads: Collected essays of Hilda J. Koopman. Vol. 3 of Routledge Leading Linguists, ed. Hilda Koopman, 357-374. London/New York: Routledge.

Korsah, Sampson. 2017. Issues in Kwa syntax: Pronouns and clausal determiners. PhD dissertation, Universität Leipzig, Leipzig.

Koster, Jan. 1975. Dutch as an SOV language. Linguistic Analysis 1 (2): 111-136.

LaCara, Nicholas. 2016a. Verb phrase movement as a window into head movement. Proceedings of the Linguistics Society of America 1 (17): 1-14.

LaCara, Nicholas. 2016b. VP movement and verb doubling. Ms.: University of Massachusetts Amherst.

Landau, Idan. 2006. Chain resolution in Hebrew VP-fronting. Syntax 9 (1): 32-66.

Landau, Idan. 2018. Missing objects in Hebrew: Argument ellipsis, not VP ellipsis. Glossa 3 (1): $76-137$. 
Larson, Richard, and Claire Lefebvre. 1991. Predicate cleft in Haitian Creole. In NELS, Vol. 21, 53-61. Amherst, MA: GLSA Publications.

Lechner, Winfried. 2001. Reduced and phrasal comparatives. Natural Language and Linguistic Theory 19 (4): $683-735$

Lechner, Winfried. 2004. Ellipsis in comparatives. Berlin, New York: Mouton de Gruyter.

Lechner, Winfried. 2007. Interpretive effects of head movement. Ms.: University of Cyprus/Stuttgart.

Legate, Julie Anne. 2014. Voice and v: Lessons from Acehnese. Cambridge, MA: MIT Press.

Legendre, Géraldine. 2001. Masked second-position effects and the linearization of functional features. In Optimality-theoretic syntax, ed. Géraldine. Legendre, Jane Grimshaw, and Sten Vikner, 241-278. Cambridge, MA: MIT Press.

Lødrup, Helge. 1990. VP-topicalization and the verb gjøre in Norwegian. Working Papers in Scandinavian Syntax 45: 3-12.

Lumsden, John S. 1990. The biclausal structure of Haitian clefts. Linguistics 28: 741-759.

Lumsden, John S., and Claire Lefebvre. 1990. Predicate-cleft constructions and why they aren't what you might think. Linguistics 28: 761-782.

Manfredi, Victor. 1993. Verb focus in the typology of Kwa/Kru and Haitian. In Focus and grammatical relations in Creole languages, ed. Francis Byrne and Donald Winford, 3-51. Amsterdam: John Benjamins.

Martinović, Martina. 2015. Feature geometry and head-splitting: Evidence from the morphosyntax of the Wolof clausal periphery. PhD dissertation, University of Chicago, Chicago, IL.

Martinović, Martina. 2017. Wolof wh-movement at the syntax-morphology interface. Natural Language and Linguistic Theory 35: 205-256.

Merchant, Jason. 2002. Swiping in Germanic. In Studies in comparative Germanic syntax: Proceedings from the 15th Workshop on Comparative Germanic Syntax, ed. Jan-Wouter Zwart and Werner Abraham, 289-316. Amsterdam/Philadelphia: John Benjamins.

Merchant, Jason. 2013. Voice and ellipsis. Linguistic Inquiry 44 (1): 77-108.

Mikkelsen, Line. 2010. On what comes first in a verb-second language. Ms., UC Berkeley

Mikkelsen, Line. 2015. VP anaphora and verb-second order in Danish. Journal of Linguistics 51 (3): 595643.

Müller, Gereon. 1998. Incomplete category fronting: A derivational approach to remnant movement in German. Dordrecht: Kluwer.

Müller, Gereon. 2009. Ergativity, accusativity, and the order of Merge and Agree. In Explorations of Phase Theory: Features and arguments, ed. Kleanthes K. Grohmann, 269-308. Berlin: Mouton de Gruyter.

Müller, Gereon. 2017. Structure removal: An argument for feature-driven Merge. Glossa 2 (1): $28-135$. https://doi.org/10.5334/gjgl.193.

Müller, Gereon. 2018. Structure removal in complex prefields. Natural Language and Linguistic Theory 36: 219-264.

Murphy, Andrew, and Zorica Puškar. 2018. Closest conjunct agreement is an illusion. Natural Language and Linguistic Theory 36 (4): 1207-1261.

Nunes, Jairo. 1995. The copy theory of movement and linearization of chains in the Minimalist Program. PhD dissertation, University of Maryland, College Park, MD.

Nunes, Jairo. 2004. Linearization of chains and sideward movement. Vol. 43 of Linguistic Inquiry Monographs. Cambridge, Mass.: MIT Press.

Oosthuizen, Johan. 1985. On the SOV status of Afrikaans. Acta Academica B, 4-22.

Ortiz de Urbina, Jon. 1989. Parameters in the grammar of Basque. Dordrecht: Foris.

Ortiz de Urbina, Jon. 1994. Verb-initial patterns in Basque and Breton. Lingua 94 (2): 125-153.

Ott, Dennis. 2014. An ellipsis approach to contrastive left-dislocation. Linguistic Inquiry 45 (2): 269-303.

Pesetsky, David. 1989. Language-particular processes and the Earliness Principle. Ms: MIT.

Pesetsky, David. 1997. Optimality Theory and syntax: Movement and pronunciation. In Optimality Theory: An overview, ed. Diana B. Archangeli and Donald Terrence Langendoen, 134-170. Malden, MA: Blackwell.

Pesetsky, David. 1998. Some optimality principles of sentence pronunciation. In Is the best good enough?, ed. Pilar Barbosa, Daniel Fox, Paul Hagstrom, Martha McGinnis, and David Pesetsky, 337-383. Cambridge, MA: MIT Press.

Piou, Nanie. 1982. Le clivage du prédicat. In Syntaxe de l'Hä̈tien, ed. Claire Lefebvre, Hélène. MagloireHolly, and Nanie Piou, 122-152. Ann Arbor, MI: Karoma Publishers. 
Platzack, Christer. 1986. COMP, INFL, and Germanic word order. In Topics in Scandinavian syntax, ed. Lars Hellan and Kristi Koch Christensen, 185-234. Dordrecht: Reidel.

Platzack, Christer. 2008. Cross linguistic variation in the realm of support verbs. Ms.: Lund University. https://ling.auf.net/lingbuzz/000766.

Platzack, Christer. 2012. Cross Germanic variation in the realm of support verbs. In Comparative Germanic Syntax: The state of the art, ed. Peter Ackema, Rhona Alcorn, Caroline Heycock, Dany Jaspers, Jeroen van Craenenbroek, and Guido Van den Wyngaerd. Vol. 191 of Linguistik Aktuell/Linguistics Today, 279-310. Amsterdam/Philadelphia: John Benjamins.

Platzack, Christer. 2013. Head movement as a phonological operation. In Diagnosing syntax: Vol. 46 of Oxford Studies in Theoretical Linguistics, ed. Lisa Lai-Shen. Cheng and Norbert Corver, 21-43. Oxford: Oxford University Press.

Pollock, Jean-Yves. 1989. Verb movement, universal grammar and the structure of IP. Linguistic Inquiry 20 (3): 365-424.

Preminger, Omer. 2011. Agreement as a fallible operation. PhD dissertation, MIT, Cambridge, MA.

Preminger, Omer. 2019. What the PCC tells us about "abstract" agreement, head movement, and locality. Glossa 4 (1): 13-142. https://doi.org/10.5334/gjgl.315.

Puškar, Zorica. 2017. Hybrid agreement: Modelling variation, hierarchiy effects and $\phi$-feature mismatches. PhD dissertation, Universität Leipzig, Leipzig.

Puškar, Zorica. 2018. Interactions of gender and number agreement: Evidence from Bosnian/Croatian/Serbian. Syntax 21 (3): 275-318.

Pylkkänen, Liina. 2008. Introducing arguments. Vol. 49 of LI monographs. Cambridge, MA: MIT Press.

Reuland, Eric. 1990. Head movement and the relation between morphology and syntax. In Yearbook of morphology 3, ed. Geert Booij and Jaap van Marle, 129-161. Dordrecht: Foris.

Řezáč, Milan. 2004. Agree and Merge. Ms.: University of the Basque Country.

Rizzi, Luigi. 1997. The fine-structure of the left periphery. In Elements of grammar, ed. Liliane Haegeman, 281-337. Dordrecht: Kluwer.

Roberts, Ian. 2000. Head movement. In Handbook of syntactic theory, ed. Mark Baltin and Chris Collins, 81-125. Oxford: Blackwell.

Roberts, Ian. 2004. The C-system in Brythonic Celtic languages, V2, and the EPP. In The structure of CP and IP (the cartography of syntactic structures, vol. 2), ed. Luigi Rizzi, 297-327. New York/Oxford: Oxford University Press.

Roberts, Ian. 2010. Agreement and head movement: Clitics, incorporation, and defective goals. Vol. 59 of Linguistic Inquiry Monographs. Cambridge, Mass.: MIT Press.

Rögnvaldsson, Eiríkur, and Höskuldur. Thráinsson. 1990. On Icelandic word order once more. In Modern Icelandic syntax. Vol. 24 of Syntax and Semantics, ed. Joan Maling and Annie Zaenen, 3-40. San Diego, CA: Academic Press.

Rohrbacher, Bernhard Wolfgang. 1999. Morphology-driven syntax: A theory of V-to-I raising and pro-drop. Vol. 15 of Linguistik Aktuell/Linguistics Today. Amsterdam: John Benjamins.

Ross, John Robert. 1974. Three batons for cognitive psychology. In Cognition and the symbolic processes, ed. Walter B. Weimar and David Stuart Palermo, 63-124. Hillsdale, NJ: Lawrence Erlbaum.

Ross, Jon Robert. 1967. Constraints on variables in syntax. PhD dissertation, MIT, Cambridge, MA.

Rouveret, Alain. 1990. X-bar theory, minimality and barrierhood in Welsh. In The syntax of modern Celtic languages, ed. Randall Hendrick. San Diego, CA: Academic Press.

Rouveret, Alain. 1994. Syntaxe du Gallois: Principes généraux et typologie. Paris: CNRS Editions.

Rouveret, Alain. 2012. VP ellipsis, phases and the syntax of morphology. Natural Language and Linguistic Theory 30: 897-963.

Sailor, Craig. 2018. The typology of head movement and ellipsis: A reply to Lipták \& Saab. Natural Language and Linguistic Theory 36: 851-875.

Santelmann, Lynn Marie. 1995. The acquisition of verb second grammar in child Swedish: Continuity of Universal Grammar in wh-questions, topicalization and verb raising. PhD dissertation, Cornell University, Ann Arbor, MI.

Santorini, Beatrice. 1989. The generalization of the verb-second constraint in the history of Yiddish. PhD dissertation, University of Pennsylvania, Philadelphia.

Santos, Ana Lúcia. 2009. Minimal answers: Ellipsis, syntax and discourse in the acquisition of European Portuguese. Vol. 48 of Language acquistion and language disorders. Amsterdam/Philadelphia: John Benjamins. 
Schafer, Robin. 1994. Non-finite predicate-initial constructions in Breton. PhD dissertation, University of California Santa Cruz, Santa Cruz, CA.

Schafer, Robin. 1995. Negation and verb second in Breton. Natural Language and Linguistic Theory 13: 135-172.

Schafer, Robin. 1997. Long head movement and information packaging in Breton. Canadian Journal of Linguistics 421: 169-203.

Schoorlemmer, Erik. 2012. Definiteness marking in German morphological variations on the same syntactic theme. Journal of Comparative Germanic Linguistics 15: 107-156.

Schoorlemmer, Erik, and Tanja Temmerman. 2012. Head movement as a PF-phenomenon: Evidence from identity under ellipsis. In Proceedings of the 29th West Coast Conference on Formal Linguistics, ed. Jaehoon Jaehoon Choi, E. Alan. Hogue, Jeffrey Punske, Deniz Tat, Jessamyn Schertz, and Alex Trueman, 232-240. Somerville, MA: Cascadilla Proceedings Project.

Schwarz, Christian. 2009. Die tun-Periphrase im Deutschen: Gebrauch und Funktion. Saarbrücken: VDM. Sproat, Richard. 1985. Welsh syntax and VSO structure. Natural Language and Linguistic Theory 3: 173216.

Stewart, Osamyimen Thompson. 1998. The serial verb construction parameter. PhD dissertation, McGill University, Montreal.

Stone, Gerald. 2002. Sorbian (upper and lower). In The Slavonic languages, ed. Bernhard Comrie and Greville G. Corbett, 593-685. London/New York: Routledge.

Takahashi, Daiko. 1994. Minimality of movement. PhD dissertation, University of Connecticut, Storrs, CT.

Tallerman, Maggie. 1996. Fronting constructions in Welsh. In The syntax of the Celtic languages: A comparative perspective, ed. Robert D. Borsley and Ian Roberts, 97-124. Cambridge: Cambridge University Press.

Taraldsen, Knut Tarald. 1986. On verb second and the functional content of syntactic categories. In Verb second phenomena in Germanic languages, ed. Hubert Haider and Martin Prinzhorn, 7-25. Dordrecht: Foris.

Teleman, Ulf, Staffan Hellberg, and Erik Andersson. 1999. Svenska Akademiens grammatik. Stockholm: Norstedts Ordbok.

Thiersch, Craig. 1978. Topics in German syntax. PhD dissertation, MIT, Cambridge, MA.

Thoms, Gary. 2012. Ellipsis licensing and verb movement in Scandinavian. Ms.: University of Glasgow.

Thráinsson, Höskuldur. 1986. V1, V2, V3 in Icelandic. In Verb second phenomena in Germanic languages, ed. Hubert Haider and Martin Prinzhorn, 169-194. Dordrecht: Foris.

Thráinsson, Höskuldur. 2007. The syntax of Icelandic. Cambridge: Cambridge University Press.

Tran, Thi Giang. 2011. The contrastive predicate construction in Vietnamese. Master's thesis, National Sun Yat-Sen University, Guangdong, China.

Travis, Lisa. 1984. Parameters and effects of word order variation. PhD dissertation, MIT, Cambridge, MA.

Trinh, Tue. 2009. A constraint on copy deletion. Theoretical Linguistics 35: 183-227.

Trinh, Tue. 2011. Edges and linearization. PhD dissertation, MIT, Cambridge, MA.

Truckenbrodt, Hubert. 2006. On the semantic motivation of syntactic verb movement to C in German. Theoretical Linguistics 32 (3): 257-306.

van Craenenbroek, Jeroen, and Liliane Haegeman. 2007. The derivation of subject-initial V2. Linguistic Inquiry 31: 167-178.

van Koppen, Marjo. 2005. One probe - two goals: Aspects of agreement in Dutch dialects. PhD dissertation, Leiden University, Leiden.

van Urk, Coppe. 2015. A uniform syntac for phrasal movement: A case study of Dinka Bor. PhD dissertation, MIT, Cambridge, MA.

Vicente, Luis. 2007. The syntax of heads and phrases: A study of verb (phrase) fronting. PhD dissertation, Leiden University, Leiden.

Vicente, Luis. 2009. An alternative to remnant movement for partial predicate fronting. Syntax 12 (2): $158-191$.

Vikner, Sten. 1995. Verb movement and expletive subjects in the Germanic languages. Oxford: Oxford University Press.

Vikner, Sten. 2001. Verb movement variation in German and Optimality Theory. Habilitation thesis, Universität Tübingen, Tübingen.

Waher, Hester. 1982. The position of the finite verb in Afrikaans. Stellenbosch Papers in Linguistics 8: 51-78. 
Watanabe, Akira. 1993. Agr-based case theory and its interaction with the A-bar-system. PhD dissertation, MIT, Cambridge, MA.

Weber, Thilo. 2017. Die tun-Periphrase im Niederdeutschen: Funktionale und formale Aspekte. Tübingen: Stauffenberg Verlag.

Wechsler, Stephen. 1991. Verb second and illocutionary force. In Views on phrase structure, ed. Katherine Leffel and Denis Bouchard, 177-191. Dordrecht: Kluwer.

Weisser, Philipp. 2015. Derived coordination: A minimalistic perspective on clause chains, converbs and asymmetric coordination. Vol. 561 of Linguistische arbeiten. Berlin: de Gruyter.

Westergaard, Marit. 2009. The acquisition of word order: Micro-cues, information structure, and economy. Amsterdam/Philadelphia: John Benjamins.

Wexler, Kenneth, and Peter Culicover. 1977. Some syntactic implications of a theory of language learnability. In Formal syntax, ed. Peter Culicover, Thomas Wasow, and Adrian Akmajian, 7-60. New York: Academic Press.

Wexler, Kenneth, and Peter Culicover. 1980. Formal principles of language acquisition. Cambridge, MA: MIT Press.

Wiklund, Anna-Lena., Gunnar Hrafn Hrafnbjargarson, Kristine Bentzen, and Porbjörg Hróarsdottir. 2007. Rethinking Scandinavian verb movement. Journal of Comparative Germanic Linguistics 10 (3): 203 233.

Wiklund, Anna-Lena., Kristine Bentzen, Gunnar Hrafn Hrafnbjargarson, and Porbjörg Hróarsdottir. 2009. On the distribution and illocution of V2 in Scandinavian that-clauses. Lingua 119 (12): 1914-1938.

Witkoś, Jacek. 1998. The syntax of clitics: Steps towards a minimalist account. Poznań: Motivex.

Yakpo, Kofi. 2009. A grammar of Pichi. Berlin/Accra: Isimu Media.

Zaenen, Annie. 1997. Contrastive dislocation in Dutch and Icelandic. In Materials on left dislocation, ed. Elena Anagnostopoulou, Henk van Riemsdijk, and Frans Zwarts, 119-148. Amsterdam: John Benjamins.

Zwart, Jan-Wouter. 1997. Morphosyntax of verb movement: A minimalist approach to the syntax of Dutch. Dordrecht: Kluwer.

Zwart, Jan-Wouter. 2017. An argument against the syntactic nature of verb movement. In Order and structure in syntax 1: Word order and syntactic structure. Vol. 1 of Open Generative Syntax, ed. Laura Bailey and Michelle Sheehan, 29-47. Berlin: Language Science Press.

Publisher's Note Springer Nature remains neutral with regard to jurisdictional claims in published maps and institutional affiliations. 